\title{
System Study: High-Pressure Safety Injection 1998-2012
}

\author{
T. E. Wierman
}

October 2013

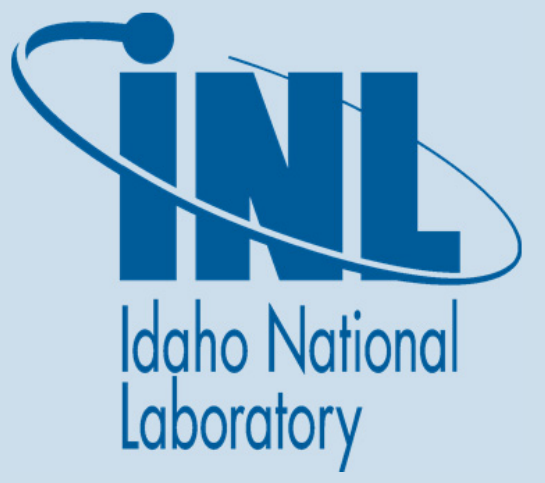

The INL is a U.S. Department of Energy National Laboratory operated by Battelle Energy Alliance 
NOTICE

This information was prepared as an account of work sponsored by an agency of the U.S. Government. Neither the U.S. Government nor any agency thereof, nor any of their employees, makes any warranty, express or implied, or assumes any legal liability or responsibility for any third party's use, or the results of such use, of any information, apparatus, product, or process disclosed herein, or represents that its use by such third party would not infringe privately owned rights. The views expressed herein are not necessarily those of the U.S. Nuclear Regulatory Commission. 


\title{
System Study: High-Pressure Safety Injection 1998-2012
}

\author{
T. E. Wierman
}

October 2013

Update Completed September 2013

\section{Idaho National Laboratory \\ Risk Assessment and Management Services Department Idaho Falls, Idaho 83415}

Prepared for the Division of Risk Assessment Office of Nuclear Regulatory Research

U.S. Nuclear Regulatory Commission

Washington, D.C. 20555

Job Code N6631 




\begin{abstract}
This report presents an unreliability evaluation of the high-pressure safety injection system (HPSI) at 69 U.S. commercial nuclear power plants. Demand, run hours, and failure data from fiscal year 1998 through 2012 for selected components were obtained from the Equipment Performance and Information Exchange (EPIX). The unreliability results are trended for the most recent 10 -year period while yearly estimates for system unreliability are provided for the entire active period. No statistically significant increasing or decreasing trends were identified in the HPSI results.
\end{abstract}


System Study

High-Pressure Safety Injection 


\section{CONTENTS}

ABSTRACT

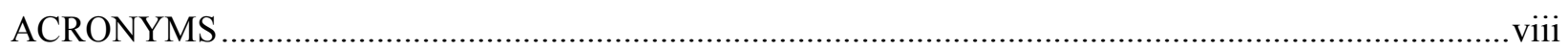

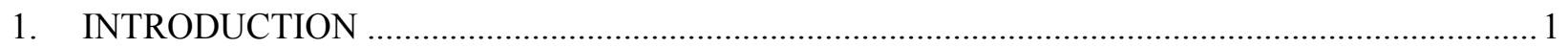

2. SUMMARY OF FINDINGS ……………………………………………………………...

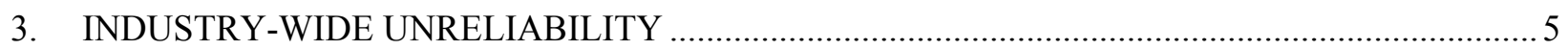

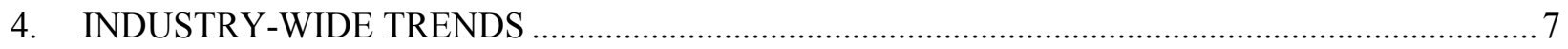

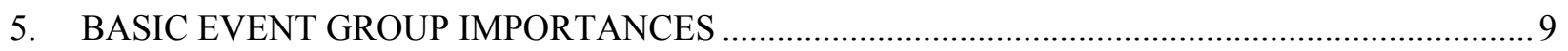

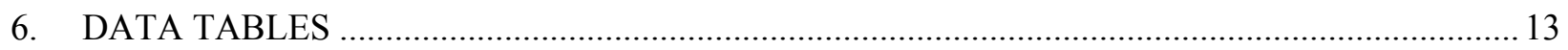

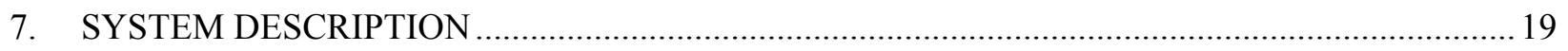

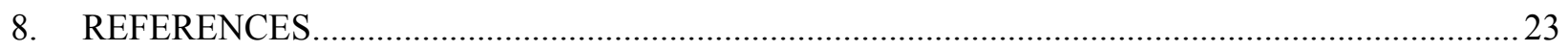

\section{FIGURES}

1. HPSI start-only mission unreliability for Class 2,3 , and 4 and industry-wide groupings..................... 6

2. HPSI 8-hour mission unreliability for Class 2,3 , and 4 and industry-wide groupings......................... 6

3. Trend of HPSI system unreliability (start-only model), as a function of fiscal year. ........................... 8

4. Trend of HPSI system unreliability ( 8 -hour model), as a function of fiscal year. ….......................... 8

5. HPSI industry-wide basic event group importances. ............................................................... 9

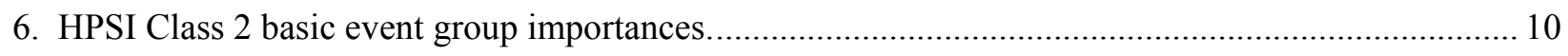

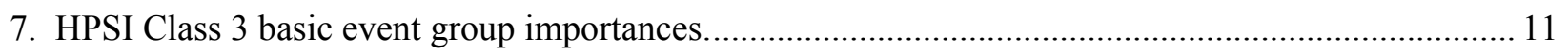

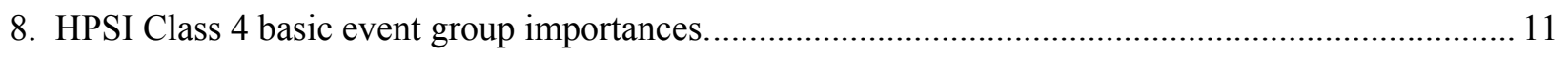

\section{TABLES}

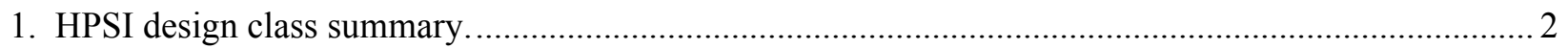




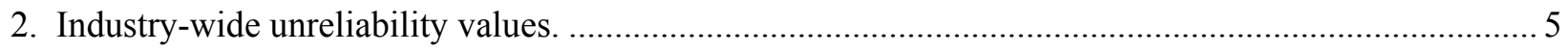

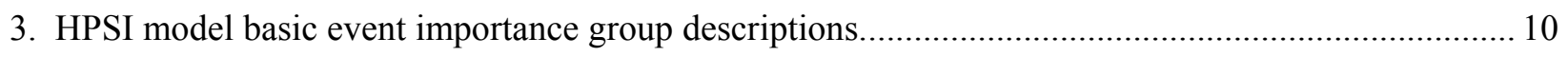

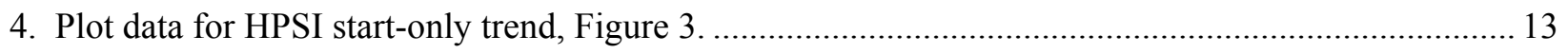

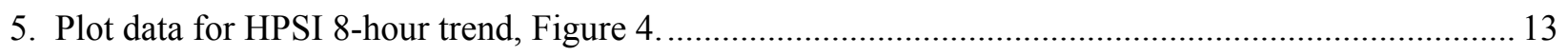

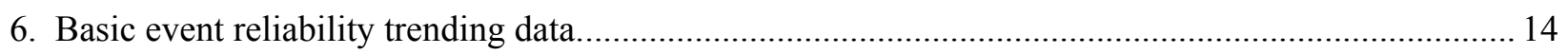

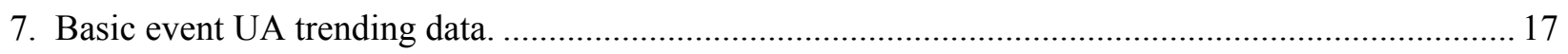

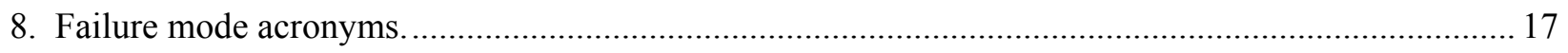

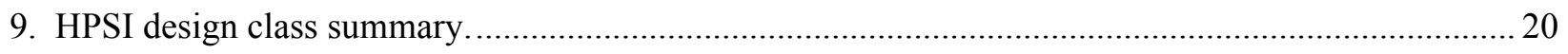




\section{ACRONYMS}

\begin{tabular}{|c|c|}
\hline AFW & auxiliary feedwater \\
\hline BWST & borated water storage tank \\
\hline $\mathrm{CCF}$ & common-cause failure \\
\hline ECCS & emergency core cooling system \\
\hline EPIX & Equipment Performance and Information Exchange \\
\hline ESFAS & engineered safety features actuation system \\
\hline FY & fiscal year \\
\hline HPSI & high-pressure safety injection \\
\hline LOCA & loss-of-coolant accident \\
\hline MFW & main feedwater \\
\hline MSPI & Mitigating Systems Performance Index \\
\hline MUT & make-up tank \\
\hline NPSH & net positive suction head \\
\hline PORV & power-operated relief valve \\
\hline PRA & probabilistic risk assessment \\
\hline PZR & pressurizer \\
\hline $\mathrm{RCP}$ & reactor coolant pump \\
\hline RCS & reactor coolant system \\
\hline RWST & refueling water storage tank \\
\hline SGTRs & steam generator tube ruptures \\
\hline SI & safety injection \\
\hline SLOCA & small loss-of-coolant accident \\
\hline SPAR & Standardized Plant Analysis Risk \\
\hline SSU & safety system unavailability \\
\hline VCT & volume control tank \\
\hline
\end{tabular}




\section{System Study: High-Pressure Safety Injection 1998-2012}

\section{INTRODUCTION}

This report presents an unreliability evaluation of the high-pressure safety injection (HPSI) system at 69 U.S. commercial nuclear power plants listed in Table 1. For each plant, the corresponding Standardized Plant Analysis Risk (SPAR) model (version model indicated in Table 1) was used in the yearly calculations. Demand, run hours, and failure data from fiscal year (FY)-98 through FY-12 for selected components in the HPSI system were obtained from the Equipment Performance and Information Exchange (EPIX) database. Train unavailability data (outages from test or maintenance) were obtained from the Reactor Oversight Process Safety System Unavailability (SSU) database (FY-98 through FY-01) and the Mitigating Systems Performance Index (MSPI) database (FY-02 through FY-12). Commoncause failure (CCF) data used in the models are from the 2010 update to the CCF database. The system unreliability results are trended for the most recent 10 -year period while yearly estimates for system unreliability are provided for the entire active period.

This report does not attempt to estimate basic event values for use in a probabilistic risk assessment (PRA). Suggested values for such use are presented in the 2010 Component Reliability Update (Reference 1), which is an update to Reference 2 (NUREG/CR-6928). Baseline HPSI unreliability results using basic event values from that report are summarized in Section 3. Trend results for HPSI (using system-specific data) are presented in Section 4. Similar to previous system study updates, Section 5 contains importance information (using the baseline results from Section 3), and Section 7 describes the HPSI.

The HPSI classes were categorized by number of pump trains (no specification on pump type) used in the SPAR models. Class 2 HPSI includes configurations that effectively result in a success criterion of one of two pumps. Class 3 HPSI includes configurations that effectively result in a success criterion of one of three pumps. HPSI designs effectively resulting in a success criterion of one of four or more are included in Class 4. Table 1 summarizes the plants and their classes.

The HPSI model is evaluated using the small loss of coolant accident (SLOCA) flag set in the SPAR model. The SLOCA flag set assumes all support systems are available and that the HPSI system is required to perform to mitigate the effects of the SLOCA initiating event. All models include failures due to unavailability while in test or maintenance. Human error has not been included in the SPAR model logic. An overview of the trending methods, glossary of terms, and abbreviations can be found in the Overview and Reference document on the Reactor Operational Experience Results and Databases web page.

Two modes of the models for the HPSI system are calculated. The HPSI start-only model is the HPSI SPAR model modified by setting all fail-to-run basic events to zero (False), setting all recovery events to False, and setting all cooling basic events to False. The 8-hour mission model includes all basic events in the HPSI SPAR model. 
Table 1. HPSI design class summary.

\begin{tabular}{|c|c|c|}
\hline Class & Plant & Version \\
\hline Class 2 & Kewaunee & 8.20 \\
\hline Class 2 & Palisades & 8.20 \\
\hline Class 2 & Palo Verde 1 & 8.20 \\
\hline Class 2 & Palo Verde 2 & 8.20 \\
\hline Class 2 & Palo Verde 3 & 8.20 \\
\hline Class 2 & Point Beach 1 & 8.20 \\
\hline Class 2 & Point Beach 2 & 8.20 \\
\hline Class 2 & Prairie Island 1 & 8.19 \\
\hline Class 2 & Prairie Island 2 & 8.19 \\
\hline Class 2 & St. Lucie 1 & 8.19 \\
\hline Class 2 & St. Lucie 2 & 8.19 \\
\hline Class 2 & Summer & 8.23 \\
\hline Class 3 & Arkansas 1 & 8.19 \\
\hline Class 3 & Arkansas 2 & 8.21 \\
\hline Class 3 & Beaver Valley 1 & 8.22 \\
\hline Class 3 & Beaver Valley 2 & 8.23 \\
\hline Class 3 & Calvert Cliffs 1 & 8.22 \\
\hline Class 3 & Calvert Cliffs 2 & 8.21 \\
\hline Class 3 & Crystal River 3 & 8.16 \\
\hline Class 3 & Farley 1 & 8.18 \\
\hline Class 3 & Farley 2 & 8.18 \\
\hline Class 3 & Fort Calhoun & 8.20 \\
\hline Class 3 & Ginna & 8.23 \\
\hline Class 3 & Harris & 8.23 \\
\hline Class 3 & Indian Point 2 & 8.19 \\
\hline Class 3 & Indian Point 3 & 8.20 \\
\hline Class 3 & Millstone 2 & 8.17 \\
\hline Class 3 & North Anna 1 & 8.20 \\
\hline Class 3 & North Anna 2 & 8.20 \\
\hline Class 3 & Oconee 1 & 8.19 \\
\hline Class 3 & Oconee 2 & 8.19 \\
\hline Class 3 & Oconee 3 & 8.19 \\
\hline Class 3 & Robinson 2 & 8.17 \\
\hline Class 3 & San Onofre 2 & 8.22 \\
\hline Class 3 & San Onofre 3 & 8.22 \\
\hline
\end{tabular}

\begin{tabular}{llr}
\hline \multicolumn{1}{c}{ Class } & \multicolumn{1}{c}{ Plant } & Version \\
\hline Class 3 & South Texas 1 & 8.17 \\
\hline Class 3 & South Texas 2 & 8.17 \\
\hline Class 3 & Surry 1 & 8.19 \\
\hline Class 3 & Surry 2 & 8.15 \\
\hline Class 3 & Three Mile Isl 1 & 8.20 \\
\hline Class 3 & Waterford 3 & 8.16 \\
\hline Class 4 & Braidwood 1 & 8.21 \\
\hline Class 4 & Braidwood 2 & 8.21 \\
\hline Class 4 & Byron 1 & 8.21 \\
\hline Class 4 & Byron 2 & 8.21 \\
\hline Class 4 & Callaway & 8.21 \\
\hline Class 4 & Catawba 1 & 8.20 \\
\hline Class 4 & Catawba 2 & 8.20 \\
\hline Class 4 & Comanche Peak 1 & 8.21 \\
\hline Class 4 & Comanche Peak 2 & 8.21 \\
\hline Class 4 & Cook 1 & 8.20 \\
\hline Class 4 & Cook 2 & 8.20 \\
\hline Class 4 & Davis-Besse & 8.19 \\
\hline Class 4 & Diablo Canyon 1 & 8.19 \\
\hline Class 4 & Diablo Canyon 2 & 8.19 \\
\hline Class 4 & McGuire 1 & 8.20 \\
\hline Class 4 & McGuire 2 & 8.20 \\
\hline Class 4 & Millstone 3 & 8.20 \\
\hline Class 4 & Salem 1 & 8.20 \\
\hline Class 4 & Salem 2 & 8.20 \\
\hline Class 4 & Seabrook & 8.20 \\
\hline Class 4 & Sequoyah 1 & 8.16 \\
\hline Class 4 & Sequoyah 2 & 8.16 \\
\hline Class 4 & Turkey Point 3 & 8.20 \\
\hline Class 4 & Turkey Point 4 & 8.20 \\
\hline Class 4 & Vogtle 1 & 8.21 \\
\hline Class 4 & Vogtle 2 & 8.21 \\
\hline Watts Bar 1 & 8.16 \\
\hline Colf Creek & 8.20 \\
\hline
\end{tabular}




\section{SUMMARY OF FINDINGS}

The results of this HPSI system unreliability study are summarized in this section. Of particular interest is the existence of any statistically significant $\mathrm{t}^{\mathrm{a}}$ increasing trends. In this update, no statistically significant increasing trends were identified in the HPSI unreliability trend results. In addition, this update identified no statistically significant decreasing trends in the HPSI results.

The industry-wide HPSI start-only and 8-hour basic event group importance was evaluated and is shown in Figure 5. In the 8-hour case, the leading contributor to HPSI system unreliability is the suction, followed by the HPI pumps, cooling support, and the injection flow path. In the start-only case, the leading contributor to HPSI system unreliability is the suction, followed by the HPI pumps, the injection flow path, and $\mathrm{AC}$ power.

a. Statistically significant is defined in terms of the 'p-value.' A p-value is a probability indicating whether to accept or reject the null hypothesis that there is no trend in the data. P-values of less than or equal to 0.05 indicate that we are $95 \%$ confident that there is a trend in the data (reject the null hypothesis of no trend.) By convention, we use the "Michelin Guide" scale: p-value $<0.05$ (statistically significant), p-value $<0.01$ (highly statistically significant); pvalue $<0.001$ (extremely statistically significant). 
System Study

High-Pressure Safety Injection 


\section{INDUSTRY-WIDE UNRELIABILITY}

The HPSI fault trees from the SPAR models were evaluated for each of the 69 operating U.S. commercial pressurized water reactor nuclear power plants with an HPSI system.

The industry-wide unreliability of the HPSI system has been estimated for two modes of operation. A start-only model and an 8-hour mission model were evaluated. The uncertainty distributions for HPSI show both plant design variability and parameter uncertainty while using industry-wide component failure data (1998-2010). ${ }^{\text {a }}$ Table 2 shows the percentiles and mean of the aggregated sample data (Latin hypercube, 1000 samples for each model) collected from the uncertainty calculations of the HPSI fault trees in the SPAR models. In Figure 1 and Figure 2, the 5th and 95th percentiles and mean point estimates are shown for each class and for the industry.

Table 2. Industry-wide unreliability values.

\begin{tabular}{cccccc}
\hline Model & HPSI Grouping & $\begin{array}{c}\text { Lower } \\
\mathbf{( 5 \% )}\end{array}$ & Median & Mean & $\begin{array}{c}\text { Upper } \\
\mathbf{( 9 5 \% )}\end{array}$ \\
\hline Start-only & Industry & $2.24 \mathrm{E}-08$ & $1.17 \mathrm{E}-05$ & $4.33 \mathrm{E}-05$ & $1.08 \mathrm{E}-04$ \\
& Class 2 & $7.56 \mathrm{E}-06$ & $4.10 \mathrm{E}-05$ & $5.47 \mathrm{E}-05$ & $1.35 \mathrm{E}-04$ \\
& Class 3 & $1.11 \mathrm{E}-06$ & $1.97 \mathrm{E}-05$ & $7.45 \mathrm{E}-05$ & $1.23 \mathrm{E}-04$ \\
& Class 4 & $7.57 \mathrm{E}-09$ & $4.45 \mathrm{E}-07$ & $7.29 \mathrm{E}-06$ & $4.09 \mathrm{E}-05$ \\
& Industry & $7.83 \mathrm{E}-08$ & $2.02 \mathrm{E}-05$ & $6.44 \mathrm{E}-05$ & $1.36 \mathrm{E}-04$ \\
& Class 2 & $1.21 \mathrm{E}-05$ & $5.16 \mathrm{E}-05$ & $6.77 \mathrm{E}-05$ & $1.62 \mathrm{E}-04$ \\
& Class 3 & $3.91 \mathrm{E}-06$ & $2.87 \mathrm{E}-05$ & $1.12 \mathrm{E}-04$ & $1.46 \mathrm{E}-04$ \\
& Class 4 & $2.56 \mathrm{E}-08$ & $1.86 \mathrm{E}-06$ & $1.65 \mathrm{E}-05$ & $9.00 \mathrm{E}-05$ \\
\hline
\end{tabular}

In Figure 1 and Figure 2, the width of the distribution for a class is affected by the differences in the plant modeling and the parameter uncertainty used in the models. Because the width is affected by the plant modeling, the width is also affected by the number of different plant models in a class. For those classes with very few plants that share a design, the width can be very small.

a. By using industry-wide component failure data, individual plant performance is not included in the distribution of results. 


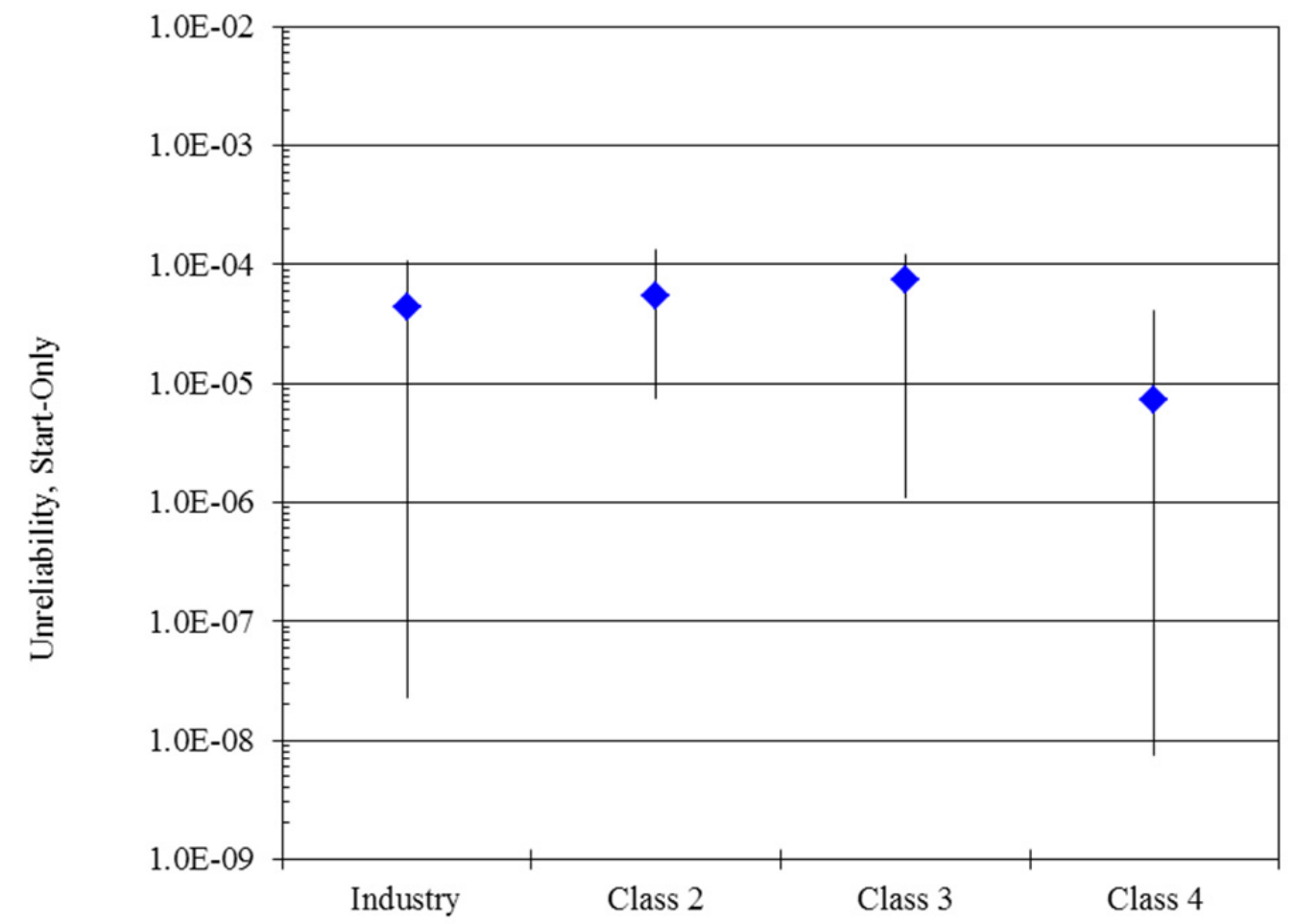

Figure 1. HPSI start-only mission unreliability for Class 2,3 , and 4 and industry-wide groupings.

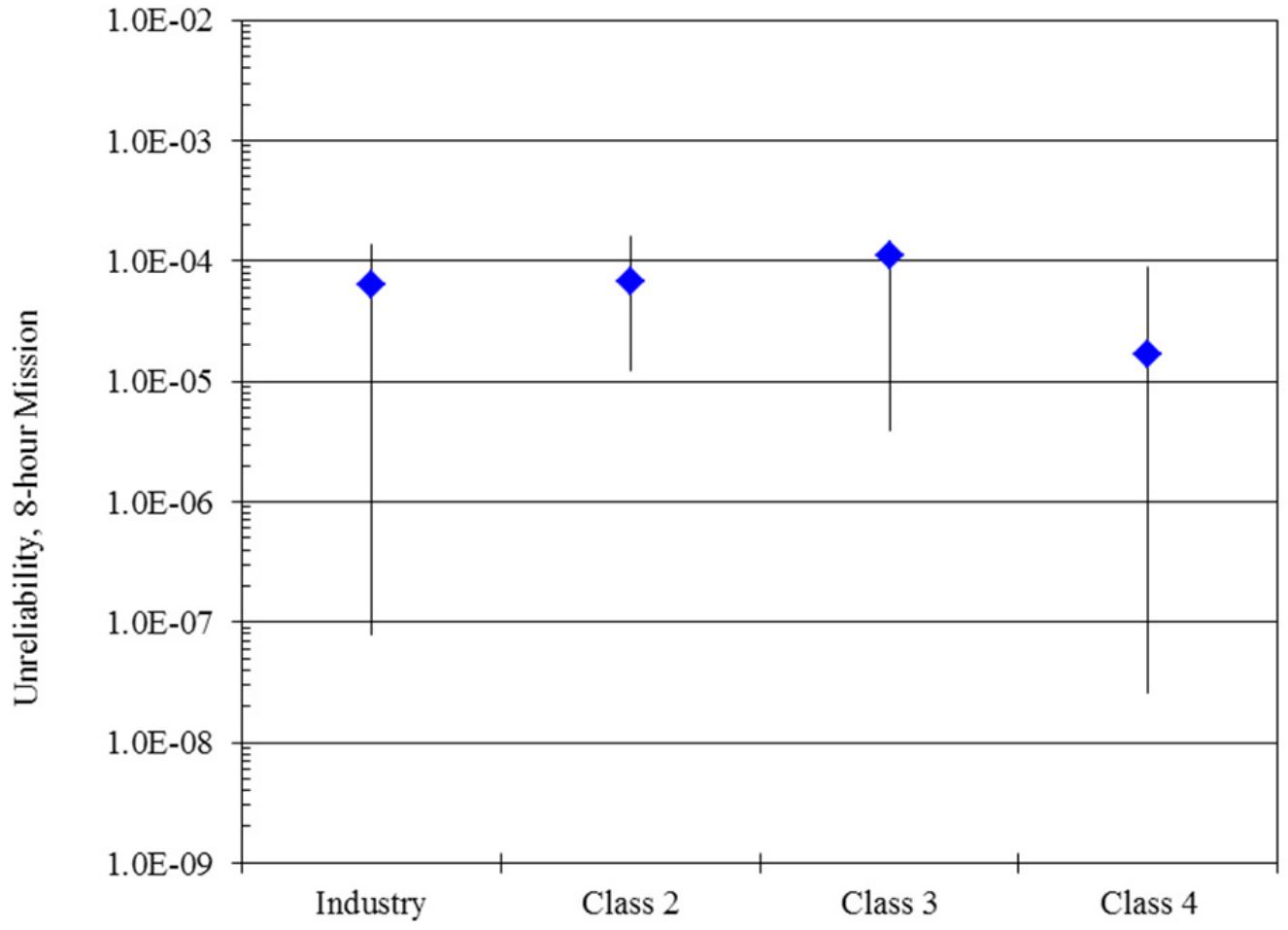

Figure 2. HPSI 8-hour mission unreliability for Class 2, 3, and 4 and industry-wide groupings. 


\section{INDUSTRY-WIDE TRENDS}

The yearly (FY-98 through FY-12) failure and demand or run time data were obtained from EPIX for the HPSI system. HPSI train maintenance unavailability data for trending are from the same time period, as reported in the ROP and EPIX. The component basic event uncertainty was calculated for the HPSI system components using the trending methods described in Section 1 and 2 of the Overview and Reference document. Tables 6 and 7 show the yearly data values for each HPSI system specific component and failure mode combination that was varied in the model. These data were loaded into the HPSI system fault tree in each SPAR model with a HPSI system (see Table 1).

The trend charts show the results of varying component reliability data over time and updating generic, relatively-flat prior distributions using data for each year. In addition, for comparison, the calculated industry-wide system reliability from this update (SPAR/EPIX) is shown. Section 4 of the Overview and Reference link on the System Studies main web page provides more detailed discussion of the trending methods. In the lower left hand corner of the trend figures, the regression method is reported.

The components that were varied in the HPSI model are

- HPSI motor-driven pump start, run, and test and maintenance.

- $\quad$ CVC motor-driven pump start, run, and test and maintenance.

- Injection valves fail-to-open.

Figure 3 shows the trend in the HPSI start-only model unreliability. Table 4 shows the data points for Figure 3. No statistically significanta trends within the industry-wide estimates of HPSI system unreliability (start-only) on a per fiscal year basis were identified. Figure 4 shows the trend in the 8-hour mission unreliability. No statistically significant trend within the industry-wide estimates of HPSI system unreliability (8-hour mission) on a per fiscal year basis was identified. Table 5 shows the data points for Figure 4.

a. Statistically significant is defined in terms of the 'p-value.' A p-value is a probability indicating whether to accept or reject the null hypothesis that there is no trend in the data. P-values of less than or equal to 0.05 indicate that we are $95 \%$ confident that there is a trend in the data (reject the null hypothesis of no trend.) By convention, we use the "Michelin Guide" scale: p-value $<0.05$ (statistically significant), p-value $<0.01$ (highly statistically significant); pvalue $<0.001$ (extremely statistically significant). 


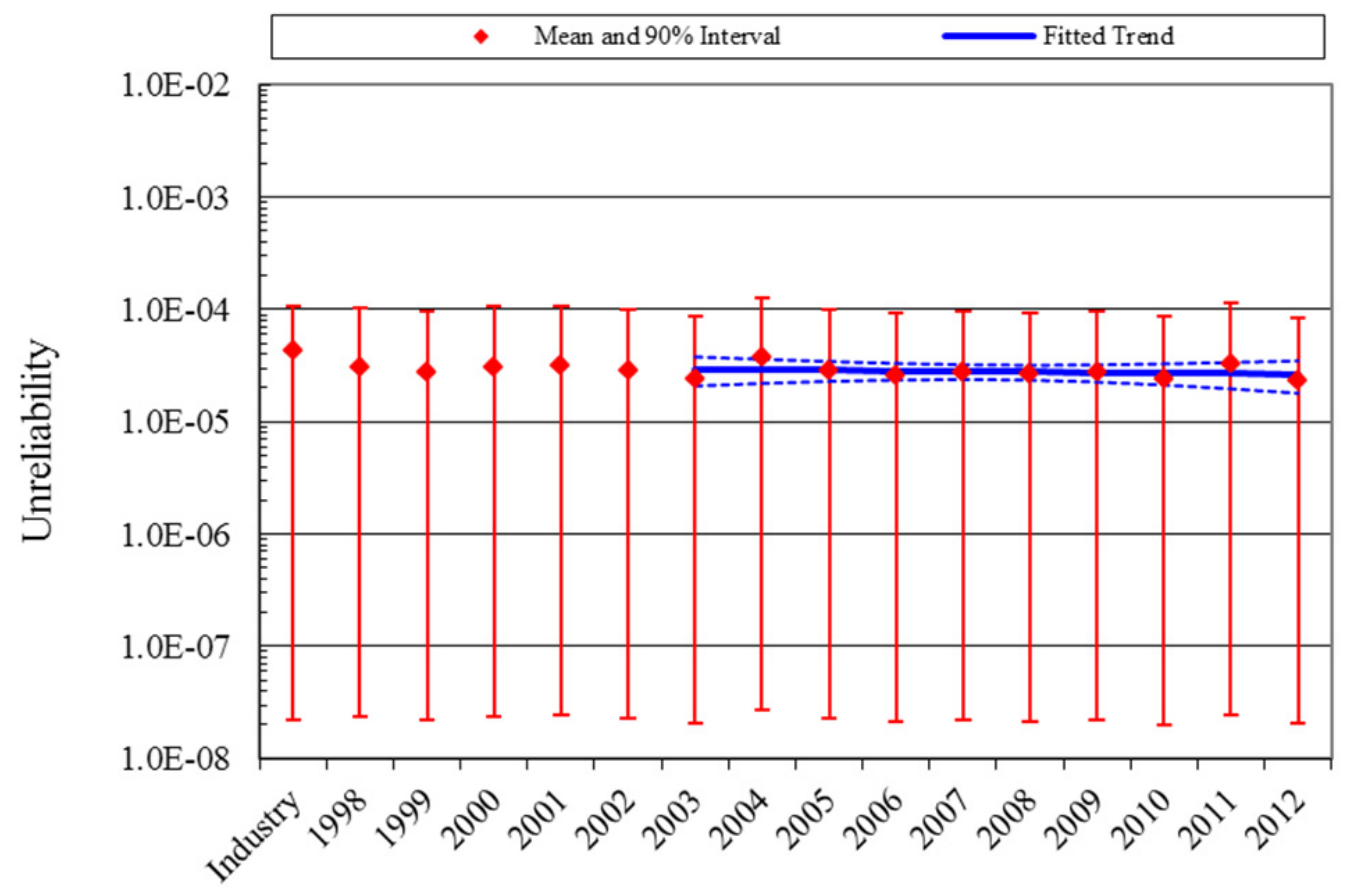

Fiscal Year

Linear model, p-value $=0.8863$

Industry HPSI Start-Only 9-19-2013

Figure 3. Trend of HPSI system unreliability (start-only model), as a function of fiscal year.

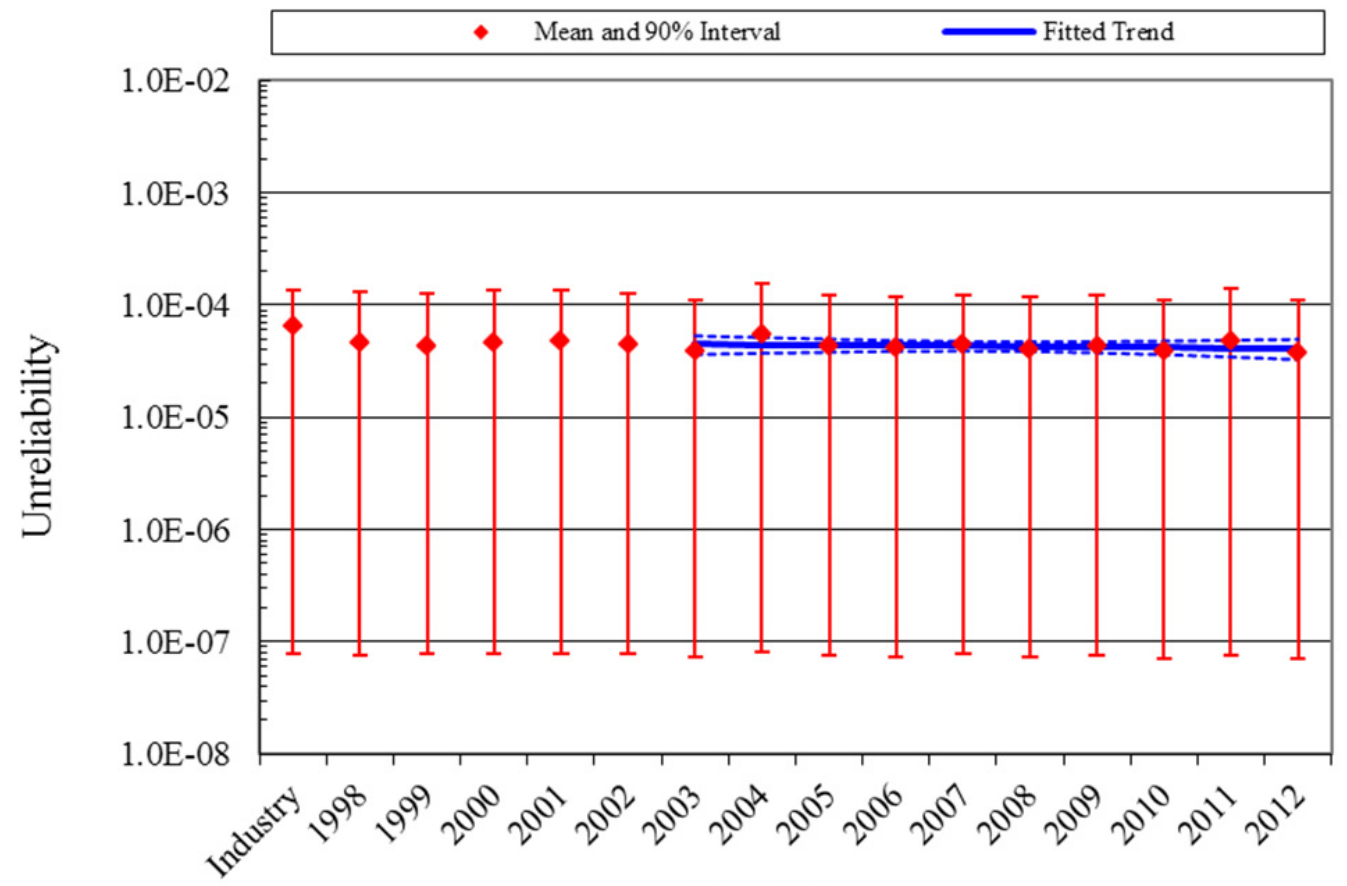

Fiscal Year

Linear model, $\mathrm{p}$-value $=0.8565$

Industry HPSI 8-hour Mission 9-19-2013

Figure 4. Trend of HPSI system unreliability (8-hour model), as a function of fiscal year. 


\section{BASIC EVENT GROUP IMPORTANCES}

The HPSI basic event group Fussell-Vesely importances were calculated for the start-only and 8-hour modes for each plant using the industry-wide data (1998-2010). These basic event group importances were then averaged across all plants to represent an industry-wide basic event group importance. The industry-wide HPSI start-only and 8-hour basic event group importances are shown in Figure 5. In the 8-hour case, the leading contributor to HPSI system unreliability is the suction, followed by the HPI pumps, cooling support, and the injection flow path. In the start-only case, the leading contributor to HPSI system unreliability is the suction, followed by the HPI pumps, the injection flow path, and AC power. For more discussion on the HPSI motor-driven pumps, see the motor-driven pump component reliability studies at NRC Reactor Operational Experience Results and Databases. Table 3 shows the SPAR model HPSI importance groups and their descriptions.

The basic event group importances were also averaged across plants of the same HPSI class to represent class basic event group importances. The class HPSI start-only and 8-hour basic event group importances are shown in Figure 6 through Figure 8.

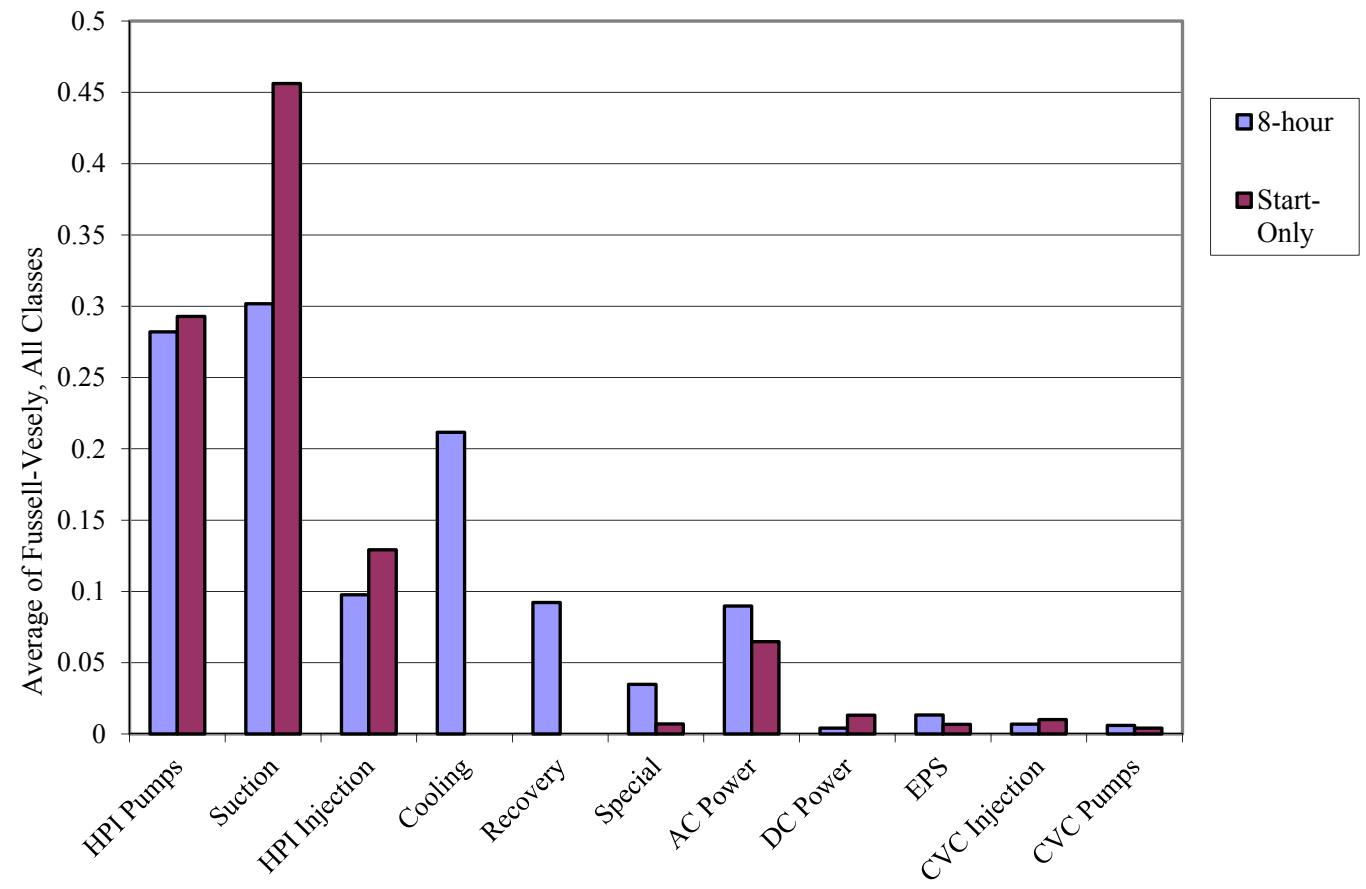

Basic Event Group

Figure 5. HPSI industry-wide basic event group importances. 
Table 3. HPSI model basic event importance group descriptions.

\begin{tabular}{|c|c|}
\hline Group & Description \\
\hline AC Power & The ac buses and circuit breakers that supply power to the HPSI pumps. \\
\hline Cooling & $\begin{array}{l}\text { The pumps, valves, and heat exchangers that provide heat removal to the HPSI motor- } \\
\text { driven pump and the HPSI room. }\end{array}$ \\
\hline CVC Injection & The motor-operated valves and check valves in the HPSI injection path \\
\hline CVC Pumps & $\begin{array}{l}\text { All basic events associated with the CVC (charging; normally running) motor-driven } \\
\text { pumps. The start, run, common-cause, and test and maintenance are included in the } \\
\text { group of basic events. }\end{array}$ \\
\hline DC Power & $\begin{array}{l}\text { The batteries and battery chargers that supply power to the HPSI motor-driven pump } \\
\text { control circuitry. }\end{array}$ \\
\hline EPS & HPSI dependency on the emergency power system. \\
\hline HPI Injection & The motor-operated valves and check valves in the HPSI injection path. \\
\hline HPI Pumps & $\begin{array}{l}\text { All basic events associated with the HPSI (generally lower head; standby) motor-driven } \\
\text { pumps. The start, run, common-cause, and test and maintenance are included in the } \\
\text { group of basic events. }\end{array}$ \\
\hline Recovery & Recovery of pump fail to start. \\
\hline Special & $\begin{array}{l}\text { Various events used in the models that are not directly associated with the HPSI } \\
\text { system. }\end{array}$ \\
\hline Suction & $\begin{array}{l}\text { The motor-operated valves and air-operated valves in the tank suction path. Includes } \\
\text { the failure of the tank. }\end{array}$ \\
\hline
\end{tabular}

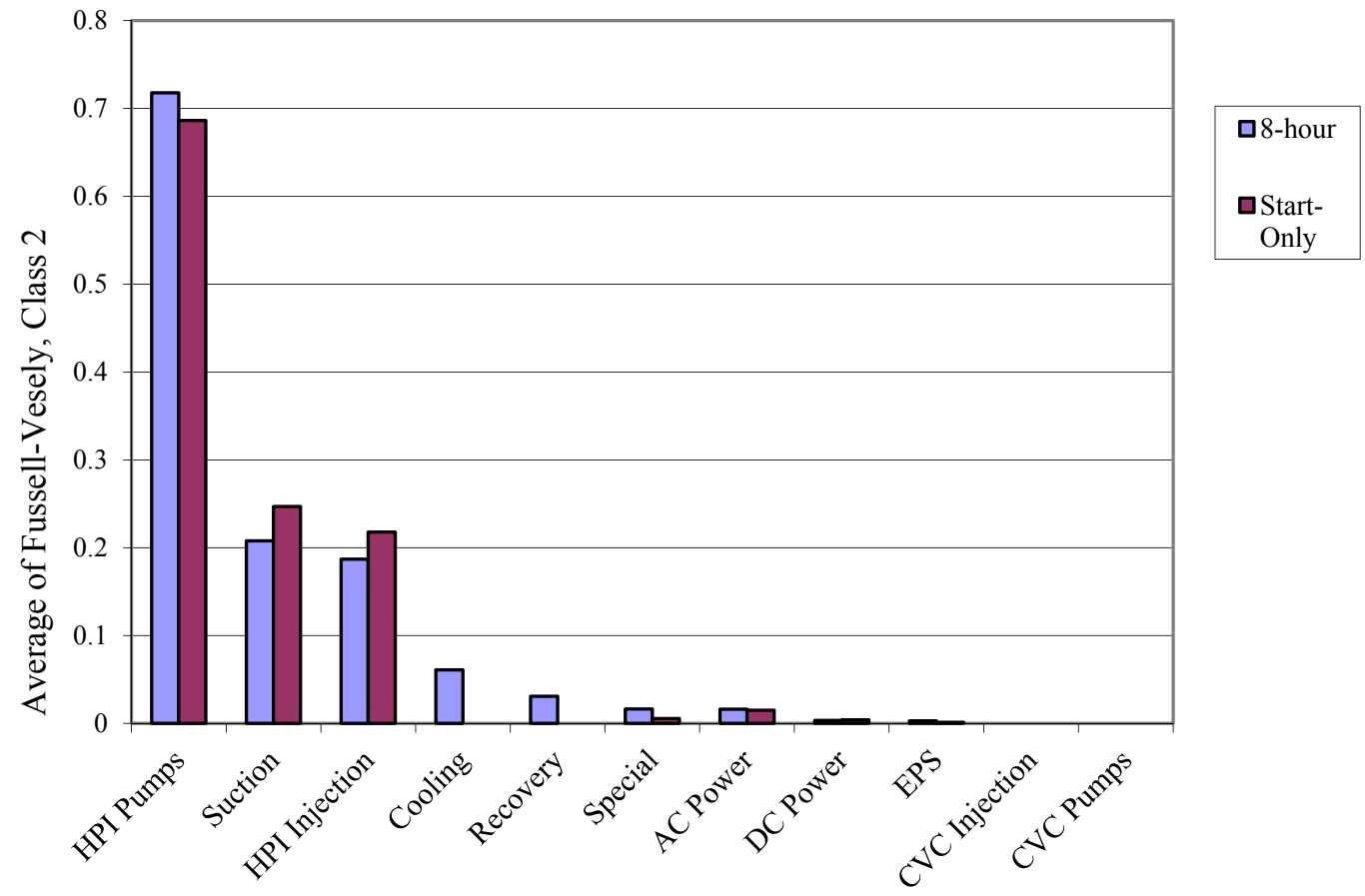

Basic Event Group

Figure 6. HPSI Class 2 basic event group importances. 


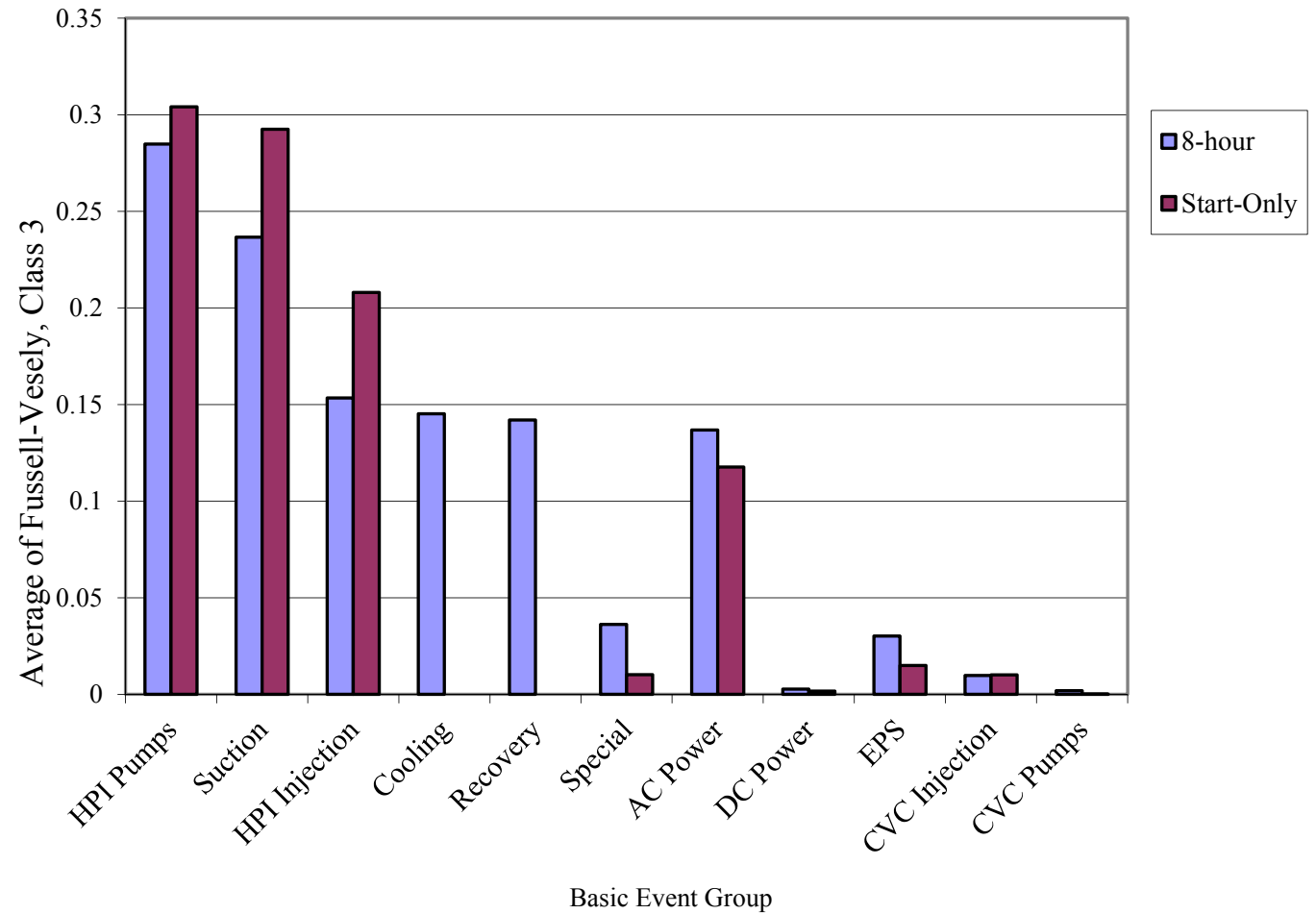

Figure 7. HPSI Class 3 basic event group importances.

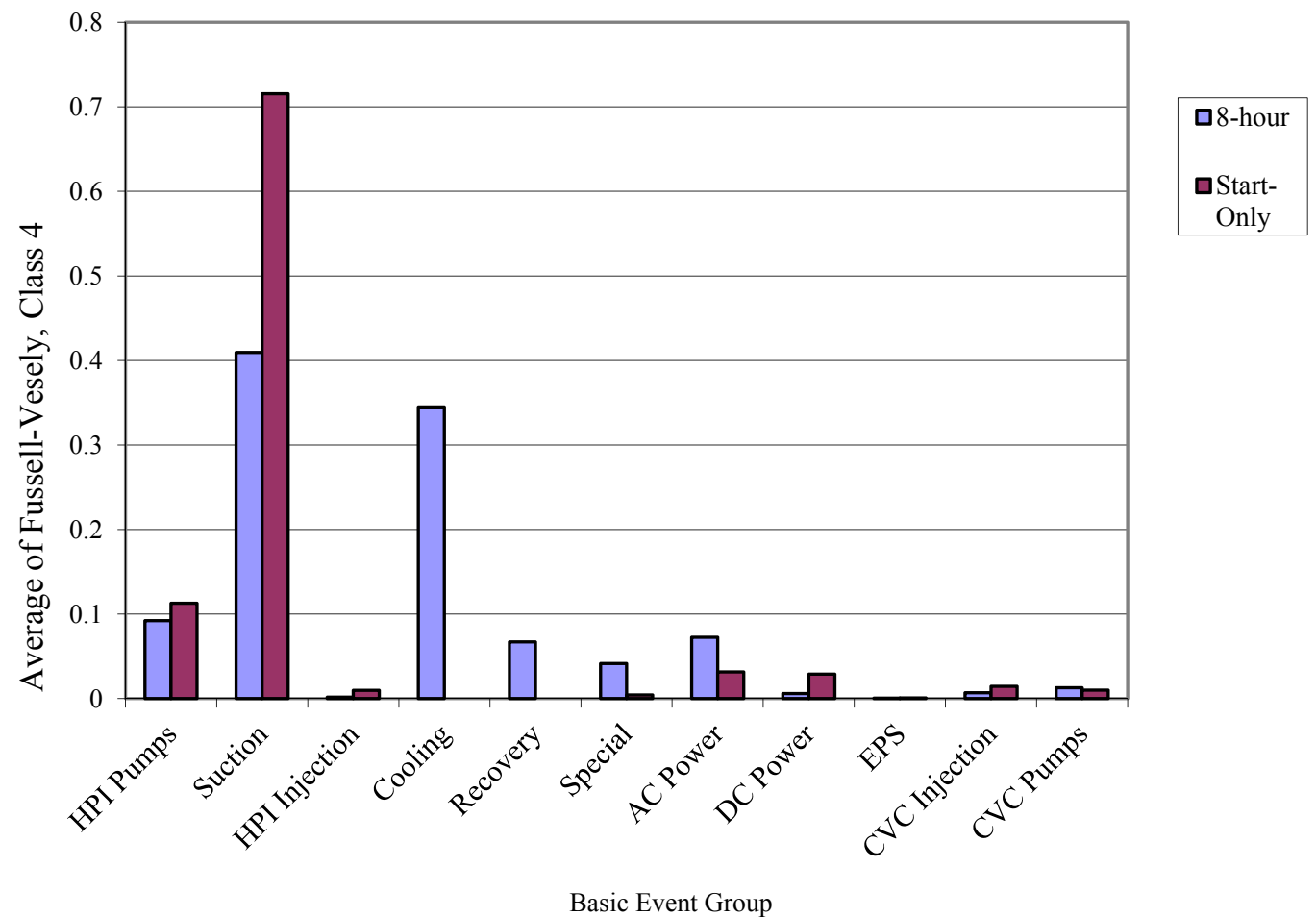

Figure 8. HPSI Class 4 basic event group importances. 
System Study

High-Pressure Safety Injection
2012 Update

October 2013 


\section{DATA TABLES}

Table 4. Plot data for HPSI start-only trend, Figure 3.

\begin{tabular}{ccccccc}
\hline & \multicolumn{2}{c}{ Regression Curve Data Points } & \multicolumn{2}{c}{ Plot Trend Error Bar Points } \\
\cline { 2 - 6 } FY/Source & Mean & $\begin{array}{c}\text { Lower } \\
\mathbf{( 5 \% )}\end{array}$ & $\begin{array}{c}\text { Upper } \\
\mathbf{( 9 5 \% )}\end{array}$ & $\begin{array}{c}\text { Lower } \\
\mathbf{( 5 \% )}\end{array}$ & $\begin{array}{c}\text { Upper } \\
\mathbf{( 9 5 \% )}\end{array}$ & Mean \\
\hline SPAR/ EPIX & & & & $2.24 \mathrm{E}-08$ & $1.08 \mathrm{E}-04$ & $4.33 \mathrm{E}-05$ \\
1998 & & & & $2.37 \mathrm{E}-08$ & $1.04 \mathrm{E}-04$ & $3.06 \mathrm{E}-05$ \\
1999 & & & & $2.24 \mathrm{E}-08$ & $9.72 \mathrm{E}-05$ & $2.81 \mathrm{E}-05$ \\
2000 & & & & $2.38 \mathrm{E}-08$ & $1.06 \mathrm{E}-04$ & $3.09 \mathrm{E}-05$ \\
\hline 2001 & & & & $2.43 \mathrm{E}-08$ & $1.08 \mathrm{E}-04$ & $3.20 \mathrm{E}-05$ \\
2002 & & & & $2.28 \mathrm{E}-08$ & $9.97 \mathrm{E}-05$ & $2.91 \mathrm{E}-05$ \\
2003 & $2.94 \mathrm{E}-05$ & $2.09 \mathrm{E}-05$ & $3.79 \mathrm{E}-05$ & $2.06 \mathrm{E}-08$ & $8.59 \mathrm{E}-05$ & $2.41 \mathrm{E}-05$ \\
2004 & $2.91 \mathrm{E}-05$ & $2.20 \mathrm{E}-05$ & $3.62 \mathrm{E}-05$ & $2.72 \mathrm{E}-08$ & $1.26 \mathrm{E}-04$ & $3.79 \mathrm{E}-05$ \\
2005 & $2.88 \mathrm{E}-05$ & $2.30 \mathrm{E}-05$ & $3.46 \mathrm{E}-05$ & $2.26 \mathrm{E}-08$ & $9.82 \mathrm{E}-05$ & $2.84 \mathrm{E}-05$ \\
2006 & $2.85 \mathrm{E}-05$ & $2.37 \mathrm{E}-05$ & $3.33 \mathrm{E}-05$ & $2.16 \mathrm{E}-08$ & $9.18 \mathrm{E}-05$ & $2.61 \mathrm{E}-05$ \\
2007 & $2.81 \mathrm{E}-05$ & $2.39 \mathrm{E}-05$ & $3.23 \mathrm{E}-05$ & $2.22 \mathrm{E}-08$ & $9.63 \mathrm{E}-05$ & $2.78 \mathrm{E}-05$ \\
2008 & $2.78 \mathrm{E}-05$ & $2.36 \mathrm{E}-05$ & $3.20 \mathrm{E}-05$ & $2.14 \mathrm{E}-08$ & $9.29 \mathrm{E}-05$ & $2.63 \mathrm{E}-05$ \\
\hline 2009 & $2.75 \mathrm{E}-05$ & $2.27 \mathrm{E}-05$ & $3.23 \mathrm{E}-05$ & $2.23 \mathrm{E}-08$ & $9.67 \mathrm{E}-05$ & $2.79 \mathrm{E}-05$ \\
\hline 2010 & $2.71 \mathrm{E}-05$ & $2.13 \mathrm{E}-05$ & $3.30 \mathrm{E}-05$ & $2.01 \mathrm{E}-08$ & $8.66 \mathrm{E}-05$ & $2.43 \mathrm{E}-05$ \\
\hline 2011 & $2.68 \mathrm{E}-05$ & $1.97 \mathrm{E}-05$ & $3.39 \mathrm{E}-05$ & $2.43 \mathrm{E}-08$ & $1.15 \mathrm{E}-04$ & $3.32 \mathrm{E}-05$ \\
\hline 2012 & $2.65 \mathrm{E}-05$ & $1.80 \mathrm{E}-05$ & $3.50 \mathrm{E}-05$ & $2.04 \mathrm{E}-08$ & $8.47 \mathrm{E}-05$ & $2.36 \mathrm{E}-05$ \\
\hline
\end{tabular}

Table 5. Plot data for HPSI 8-hour trend, Figure 4.

\begin{tabular}{ccccccc}
\hline & \multicolumn{2}{c}{ Regression Curve Data Points } & \multicolumn{2}{c}{ Plot Trend Error Bar Points } \\
\cline { 2 - 7 } FY/Source & Mean & $\begin{array}{c}\text { Lower } \\
\mathbf{( 5 \% )}\end{array}$ & $\begin{array}{c}\text { Upper } \\
\mathbf{( 9 5 \% )}\end{array}$ & $\begin{array}{c}\text { Lower } \\
\mathbf{( 5 \% )}\end{array}$ & $\begin{array}{c}\text { Upper } \\
\mathbf{( 9 5 \% )}\end{array}$ & Mean \\
\hline $\begin{array}{c}\text { SPAR/ EPIX } \\
1998\end{array}$ & & & & $7.83 \mathrm{E}-08$ & $1.36 \mathrm{E}-04$ & $6.44 \mathrm{E}-05$ \\
\hline 1999 & & & & $7.55 \mathrm{E}-08$ & $1.29 \mathrm{E}-04$ & $4.56 \mathrm{E}-05$ \\
\hline 2000 & & & & $7.71 \mathrm{E}-08$ & $1.26 \mathrm{E}-04$ & $4.37 \mathrm{E}-05$ \\
\hline 2001 & & & & $7.85 \mathrm{E}-08$ & $1.34 \mathrm{E}-04$ & $4.67 \mathrm{E}-05$ \\
\hline 2002 & & & & $7.84 \mathrm{E}-08$ & $1.35 \mathrm{E}-04$ & $4.79 \mathrm{E}-05$ \\
\hline 2003 & $4.48 \mathrm{E}-05$ & $3.63 \mathrm{E}-05$ & $5.33 \mathrm{E}-05$ & $7.26 \mathrm{E}-08$ & $1.12 \mathrm{E}-04$ & $3.90 \mathrm{E}-05$ \\
\hline 2004 & $4.44 \mathrm{E}-05$ & $3.73 \mathrm{E}-05$ & $5.15 \mathrm{E}-05$ & $8.25 \mathrm{E}-08$ & $1.54 \mathrm{E}-04$ & $5.39 \mathrm{E}-05$ \\
\hline 2005 & $4.40 \mathrm{E}-05$ & $3.82 \mathrm{E}-05$ & $4.99 \mathrm{E}-05$ & $7.46 \mathrm{E}-08$ & $1.24 \mathrm{E}-04$ & $4.30 \mathrm{E}-05$ \\
\hline 2006 & $4.37 \mathrm{E}-05$ & $3.89 \mathrm{E}-05$ & $4.85 \mathrm{E}-05$ & $7.38 \mathrm{E}-08$ & $1.18 \mathrm{E}-04$ & $4.11 \mathrm{E}-05$ \\
\hline 2007 & $4.33 \mathrm{E}-05$ & $3.91 \mathrm{E}-05$ & $4.75 \mathrm{E}-05$ & $7.73 \mathrm{E}-08$ & $1.25 \mathrm{E}-04$ & $4.40 \mathrm{E}-05$ \\
\hline 2008 & $4.29 \mathrm{E}-05$ & $3.87 \mathrm{E}-05$ & $4.71 \mathrm{E}-05$ & $7.28 \mathrm{E}-08$ & $1.17 \mathrm{E}-04$ & $4.08 \mathrm{E}-05$ \\
\hline 2009 & $4.25 \mathrm{E}-05$ & $3.77 \mathrm{E}-05$ & $4.73 \mathrm{E}-05$ & $7.66 \mathrm{E}-08$ & $1.23 \mathrm{E}-04$ & $4.36 \mathrm{E}-05$ \\
\hline 2010 & $4.21 \mathrm{E}-05$ & $3.63 \mathrm{E}-05$ & $4.79 \mathrm{E}-05$ & $7.16 \mathrm{E}-08$ & $1.12 \mathrm{E}-04$ & $3.87 \mathrm{E}-05$ \\
\hline 2011 & $4.17 \mathrm{E}-05$ & $3.46 \mathrm{E}-05$ & $4.88 \mathrm{E}-05$ & $7.68 \mathrm{E}-08$ & $1.39 \mathrm{E}-04$ & $4.85 \mathrm{E}-05$ \\
\hline 2012 & $4.13 \mathrm{E}-05$ & $3.28 \mathrm{E}-05$ & $4.98 \mathrm{E}-05$ & $7.15 \mathrm{E}-08$ & $1.10 \mathrm{E}-04$ & $3.80 \mathrm{E}-05$ \\
\hline
\end{tabular}


Table 6. Basic event reliability trending data.

\begin{tabular}{|c|c|c|c|c|c|c|c|c|}
\hline \multirow{2}{*}{$\begin{array}{l}\text { Failure } \\
\text { Mode }\end{array}$} & \multirow[b]{2}{*}{ Component } & \multirow[b]{2}{*}{ Year } & \multirow{2}{*}{$\begin{array}{l}\text { Number of } \\
\text { Failures }\end{array}$} & \multirow{2}{*}{$\begin{array}{l}\text { Demands/ } \\
\text { Run Hours }\end{array}$} & \multicolumn{4}{|c|}{ Bayesian Update } \\
\hline & & & & & Mean & Post A & Post B & Distribution \\
\hline FTOC & AOV & 1998 & 0 & 315.5 & $7.49 \mathrm{E}-04$ & 1.1 & 1483.5 & Beta \\
\hline FTOC & AOV & 1999 & 0 & 344.4 & $7.35 \mathrm{E}-04$ & 1.1 & 1512.4 & Beta \\
\hline FTOC & AOV & 2000 & 0 & 380.7 & 7.17E-04 & 1.1 & 1548.7 & Beta \\
\hline FTOC & AOV & 2001 & 0 & 291.1 & $7.62 \mathrm{E}-04$ & 1.1 & 1459.1 & Beta \\
\hline FTOC & AOV & 2002 & 0 & 328.1 & $7.43 \mathrm{E}-04$ & 1.1 & 1496.1 & Beta \\
\hline FTOC & AOV & 2003 & 2 & 322.3 & $2.09 \mathrm{E}-03$ & 3.1 & 1488.3 & Beta \\
\hline FTOC & AOV & 2004 & 0 & 309.2 & $7.52 \mathrm{E}-04$ & 1.1 & 1477.2 & Beta \\
\hline FTOC & AOV & 2005 & 0 & 266.7 & $7.75 \mathrm{E}-04$ & 1.1 & 1434.7 & Beta \\
\hline FTOC & AOV & 2006 & 1 & 267.4 & $1.47 \mathrm{E}-03$ & 2.1 & 1434.4 & Beta \\
\hline FTOC & AOV & 2007 & 0 & 269.7 & 7.73E-04 & 1.1 & 1437.7 & Beta \\
\hline FTOC & AOV & 2008 & 1 & 268.4 & $1.47 \mathrm{E}-03$ & 2.1 & 1435.4 & Beta \\
\hline FTOC & AOV & 2009 & 0 & 267.9 & 7.74E-04 & 1.1 & 1435.9 & Beta \\
\hline FTOC & AOV & 2010 & 0 & 268.7 & 7.73E-04 & 1.1 & 1436.7 & Beta \\
\hline FTOC & AOV & 2011 & 3 & 269.0 & $2.86 \mathrm{E}-03$ & 4.1 & 1434.0 & Beta \\
\hline FTOC & AOV & 2012 & 0 & 269.3 & $7.73 \mathrm{E}-04$ & 1.1 & 1437.3 & Beta \\
\hline FTOC & MOV & 1998 & 4 & 5286.1 & $8.16 \mathrm{E}-04$ & 6.0 & 7405.1 & Beta \\
\hline FTOC & MOV & 1999 & 5 & 5395.0 & $9.37 \mathrm{E}-04$ & 7.0 & 7513.0 & Beta \\
\hline FTOC & MOV & 2000 & 6 & 5483.7 & 1.06E-03 & 8.0 & 7600.7 & Beta \\
\hline FTOC & MOV & 2001 & 4 & 5343.3 & $8.10 \mathrm{E}-04$ & 6.0 & 7462.3 & Beta \\
\hline FTOC & MOV & 2002 & 3 & 5274.4 & $6.82 \mathrm{E}-04$ & 5.0 & 7394.4 & Beta \\
\hline FTOC & MOV & 2003 & 2 & 5203.5 & $5.52 \mathrm{E}-04$ & 4.0 & 7324.5 & Beta \\
\hline FTOC & MOV & 2004 & 6 & 5569.1 & $1.05 \mathrm{E}-03$ & 8.0 & 7686.1 & Beta \\
\hline FTOC & MOV & 2005 & 5 & 5314.2 & $9.47 \mathrm{E}-04$ & 7.0 & 7432.2 & Beta \\
\hline FTOC & MOV & 2006 & 3 & 4779.5 & 7.31E-04 & 5.0 & 6899.5 & Beta \\
\hline FTOC & MOV & 2007 & 3 & 4855.6 & 7.23E-04 & 5.0 & 6975.6 & Beta \\
\hline FTOC & MOV & 2008 & 1 & 5018.5 & $4.26 \mathrm{E}-04$ & 3.0 & 7140.5 & Beta \\
\hline FTOC & MOV & 2009 & 3 & 4839 & $7.25 \mathrm{E}-04$ & 5.0 & 6959 & Beta \\
\hline FTOC & MOV & 2010 & 3 & 4917 & 7.17E-04 & 5.0 & 7037 & Beta \\
\hline FTOC & MOV & 2011 & 2 & 4862 & $5.79 \mathrm{E}-04$ & 4.0 & 6983 & Beta \\
\hline FTOC & MOV & 2012 & 1 & 4789 & $4.41 \mathrm{E}-04$ & 3.0 & 6911 & Beta \\
\hline FTOP & AOV & 1998 & 0 & 569400 & $2.26 \mathrm{E}-07$ & 1.4 & 6288400 & Gamma \\
\hline FTOP & AOV & 1999 & 0 & 569400 & $2.26 \mathrm{E}-07$ & 1.4 & 6288400 & Gamma \\
\hline FTOP & AOV & 2000 & 0 & 569400 & $2.26 \mathrm{E}-07$ & 1.4 & 6288400 & Gamma \\
\hline FTOP & AOV & 2001 & 1 & 613200 & $3.82 \mathrm{E}-07$ & 2.4 & 6332200 & Gamma \\
\hline FTOP & AOV & 2002 & 0 & 613200 & $2.24 \mathrm{E}-07$ & 1.4 & 6332200 & Gamma \\
\hline FTOP & AOV & 2003 & 0 & 613200 & $2.24 \mathrm{E}-07$ & 1.4 & 6332200 & Gamma \\
\hline FTOP & AOV & 2004 & 0 & 613200 & $2.24 \mathrm{E}-07$ & 1.4 & 6332200 & Gamma \\
\hline FTOP & AOV & 2005 & 0 & 613200 & $2.24 \mathrm{E}-07$ & 1.4 & 6332200 & Gamma \\
\hline FTOP & AOV & 2006 & 0 & 639480 & $2.23 \mathrm{E}-07$ & 1.4 & 6358480 & Gamma \\
\hline FTOP & AOV & 2007 & 0 & 613200 & $2.24 \mathrm{E}-07$ & 1.4 & 6332200 & Gamma \\
\hline FTOP & AOV & 2008 & 0 & 613200 & $2.24 \mathrm{E}-07$ & 1.4 & 6332200 & Gamma \\
\hline FTOP & AOV & 2009 & 0 & 613200 & $2.24 \mathrm{E}-07$ & 1.4 & 6332200 & Gamma \\
\hline FTOP & AOV & 2010 & 0 & 613200 & $2.24 \mathrm{E}-07$ & 1.4 & 6332200 & Gamma \\
\hline FTOP & AOV & 2011 & 0 & 613200 & $2.24 \mathrm{E}-07$ & 1.4 & 6332200 & Gamma \\
\hline FTOP & AOV & 2012 & 0 & 613200 & $2.24 \mathrm{E}-07$ & 1.4 & 6332200 & Gamma \\
\hline
\end{tabular}


Table 6. (continued).

\begin{tabular}{|c|c|c|c|c|c|c|c|c|}
\hline \multirow{2}{*}{$\begin{array}{l}\text { Failure } \\
\text { Mode }\end{array}$} & \multirow[b]{2}{*}{ Component } & \multirow[b]{2}{*}{ Year } & \multirow{2}{*}{$\begin{array}{l}\text { Number of } \\
\text { Failures }\end{array}$} & \multirow{2}{*}{$\begin{array}{l}\text { Demands/ } \\
\text { Run Hours }\end{array}$} & \multicolumn{4}{|c|}{ Bayesian Update } \\
\hline & & & & & Mean & Post A & Post B & Distribution \\
\hline FTOP & MOV & 1998 & 0 & 8383320 & 4.79E-08 & 1.5 & 30433320 & Gamma \\
\hline FTOP & MOV & 1999 & 0 & 8383320 & $4.79 \mathrm{E}-08$ & 1.5 & 30433320 & Gamma \\
\hline FTOP & MOV & 2000 & 0 & 8383320 & $4.79 \mathrm{E}-08$ & 1.5 & 30433320 & Gamma \\
\hline FTOP & MOV & 2001 & 0 & 8383320 & 4.79E-08 & 1.5 & 30433320 & Gamma \\
\hline FTOP & MOV & 2002 & 2 & 8365800 & $1.14 \mathrm{E}-07$ & 3.5 & 30415800 & Gamma \\
\hline FTOP & MOV & 2003 & 0 & 8365800 & $4.79 \mathrm{E}-08$ & 1.5 & 30415800 & Gamma \\
\hline FTOP & MOV & 2004 & 0 & 8365800 & 4.79E-08 & 1.5 & 30415800 & Gamma \\
\hline FTOP & MOV & 2005 & 0 & 8400840.0 & 4.79E-08 & 1.5 & 30450840.0 & Gamma \\
\hline FTOP & MOV & 2006 & 0 & 8427120.0 & $4.78 \mathrm{E}-08$ & 1.5 & 30477120.0 & Gamma \\
\hline FTOP & MOV & 2007 & 0 & 8418360.0 & 4.79E-08 & 1.5 & 30468360.0 & Gamma \\
\hline FTOP & MOV & 2008 & 0 & 8418360.0 & 4.79E-08 & 1.5 & 30468360.0 & Gamma \\
\hline FTOP & MOV & 2009 & 0 & 8453400.0 & $4.78 \mathrm{E}-08$ & 1.5 & 30503400.0 & Gamma \\
\hline FTOP & MOV & 2010 & 1 & 8427120.0 & 8.07E-08 & 2.5 & 30477120.0 & Gamma \\
\hline FTOP & MOV & 2011 & 1 & 8549760.0 & 8.03E-08 & 2.5 & 30599760.0 & Gamma \\
\hline FTOP & MOV & 2012 & 0 & 8602320.0 & $4.76 \mathrm{E}-08$ & 1.5 & 30652320.0 & Gamma \\
\hline $\mathrm{FTR}<1 \mathrm{H}$ & MDP & 1998 & 0 & 2926.8 & $1.03 \mathrm{E}-04$ & 1.8 & 17716.8 & Gamma \\
\hline $\mathrm{FTR}<1 \mathrm{H}$ & MDP & 1999 & 0 & 3227.2 & $1.01 \mathrm{E}-04$ & 1.8 & 18017.2 & Gamma \\
\hline $\mathrm{FTR}<1 \mathrm{H}$ & MDP & 2000 & 0 & 3312.1 & $1.01 \mathrm{E}-04$ & 1.8 & 18102.1 & Gamma \\
\hline $\mathrm{FTR}<1 \mathrm{H}$ & MDP & 2001 & 1 & 3068.0 & $1.58 \mathrm{E}-04$ & 2.8 & 17858.0 & Gamma \\
\hline $\mathrm{FTR}<1 \mathrm{H}$ & MDP & 2002 & 0 & 2985.7 & $1.02 \mathrm{E}-04$ & 1.8 & 17775.7 & Gamma \\
\hline $\mathrm{FTR}<1 \mathrm{H}$ & MDP & 2003 & 0 & 3149.0 & $1.01 \mathrm{E}-04$ & 1.8 & 17939.0 & Gamma \\
\hline $\mathrm{FTR}<1 \mathrm{H}$ & MDP & 2004 & 0 & 3126.9 & $1.02 \mathrm{E}-04$ & 1.8 & 17916.9 & Gamma \\
\hline $\mathrm{FTR}<1 \mathrm{H}$ & MDP & 2005 & 0 & 3057.8 & $1.02 \mathrm{E}-04$ & 1.8 & 17847.8 & Gamma \\
\hline $\mathrm{FTR}<1 \mathrm{H}$ & MDP & 2006 & 0 & 3000.7 & $1.02 \mathrm{E}-04$ & 1.8 & 17790.7 & Gamma \\
\hline $\mathrm{FTR}<1 \mathrm{H}$ & MDP & 2007 & 1 & 3005.0 & $1.58 \mathrm{E}-04$ & 2.8 & 17795.0 & Gamma \\
\hline $\mathrm{FTR}<1 \mathrm{H}$ & MDP & 2008 & 0 & 3089.5 & $1.02 \mathrm{E}-04$ & 1.8 & 17879.5 & Gamma \\
\hline $\mathrm{FTR}<1 \mathrm{H}$ & MDP & 2009 & 1 & 2942.1 & $1.59 \mathrm{E}-04$ & 2.8 & 17732.1 & Gamma \\
\hline $\mathrm{FTR}<1 \mathrm{H}$ & MDP & 2010 & 0 & 2984.7 & $1.02 \mathrm{E}-04$ & 1.8 & 17774.7 & Gamma \\
\hline $\mathrm{FTR}<1 \mathrm{H}$ & MDP & 2011 & 0 & 3032.3 & $1.02 \mathrm{E}-04$ & 1.8 & 17822.3 & Gamma \\
\hline $\mathrm{FTR}<1 \mathrm{H}$ & MDP & 2012 & 0 & 2700.7 & $1.04 \mathrm{E}-04$ & 1.8 & 17490.7 & Gamma \\
\hline FTR $>1 \mathrm{H}$ & MDP & 1998 & 1 & 120632.2 & $9.10 \mathrm{E}-06$ & 1.8 & 195642.2 & Gamma \\
\hline $\mathrm{FTR}>1 \mathrm{H}$ & MDP & 1999 & 3 & 111842.6 & $2.02 \mathrm{E}-05$ & 3.8 & 186852.6 & Gamma \\
\hline $\mathrm{FTR}>1 \mathrm{H}$ & MDP & 2000 & 3 & 101297.1 & $2.14 \mathrm{E}-05$ & 3.8 & 176307.2 & Gamma \\
\hline $\mathrm{FTR}>1 \mathrm{H}$ & MDP & 2001 & 1 & 98843.2 & $1.02 \mathrm{E}-05$ & 1.8 & 173853.2 & Gamma \\
\hline $\mathrm{FTR}>1 \mathrm{H}$ & MDP & 2002 & 3 & 100242.6 & $2.16 \mathrm{E}-05$ & 3.8 & 175252.6 & Gamma \\
\hline $\mathrm{FTR}>1 \mathrm{H}$ & MDP & 2003 & 1 & 99957.5 & $1.02 \mathrm{E}-05$ & 1.8 & 174967.5 & Gamma \\
\hline $\mathrm{FTR}>1 \mathrm{H}$ & MDP & 2004 & 3 & 108235.7 & $2.06 \mathrm{E}-05$ & 3.8 & 183245.7 & Gamma \\
\hline FTR $>1 \mathrm{H}$ & MDP & 2005 & 1 & 111310.7 & $9.56 \mathrm{E}-06$ & 1.8 & 186320.7 & Gamma \\
\hline $\mathrm{FTR}>1 \mathrm{H}$ & MDP & 2006 & 1 & 105243.4 & $9.88 \mathrm{E}-06$ & 1.8 & 180253.4 & Gamma \\
\hline $\mathrm{FTR}>1 \mathrm{H}$ & MDP & 2007 & 2 & 108260.1 & $1.52 \mathrm{E}-05$ & 2.8 & 183270.1 & Gamma \\
\hline FTR $>1 \mathrm{H}$ & MDP & 2008 & 0 & 113690.8 & 4.14E-06 & 0.8 & 188700.8 & Gamma \\
\hline $\mathrm{FTR}>1 \mathrm{H}$ & MDP & 2009 & 1 & 110122.3 & $9.62 \mathrm{E}-06$ & 1.8 & 185132.3 & Gamma \\
\hline $\mathrm{FTR}>1 \mathrm{H}$ & MDP & 2010 & 0 & 106468.1 & 4.30E-06 & 0.8 & 181478.2 & Gamma \\
\hline $\mathrm{FTR}>1 \mathrm{H}$ & MDP & 2011 & 1 & 104524.1 & $9.92 \mathrm{E}-06$ & 1.8 & 179534.1 & Gamma \\
\hline $\mathrm{FTR}>1 \mathrm{H}$ & MDP & 2012 & 0 & 103195.6 & $4.38 \mathrm{E}-06$ & 0.8 & 178205.6 & Gamma \\
\hline
\end{tabular}


Table 6. (continued).

\begin{tabular}{|c|c|c|c|c|c|c|c|c|}
\hline \multirow{2}{*}{$\begin{array}{c}\text { Failure } \\
\text { Mode }\end{array}$} & \multirow[b]{2}{*}{ Component } & \multirow[b]{2}{*}{ Year } & \multirow{2}{*}{$\begin{array}{l}\text { Number of } \\
\text { Failures }\end{array}$} & \multirow{2}{*}{$\begin{array}{l}\text { Demands/ } \\
\text { Run Hours }\end{array}$} & \multicolumn{4}{|c|}{ Bayesian Update } \\
\hline & & & & & Mean & Post A & Post B & Distribution \\
\hline FTS & MDP & 1998 & 4 & 2926.8 & $1.19 \mathrm{E}-03$ & 5.9 & 4976.8 & Beta \\
\hline FTS & MDP & 1999 & 2 & 3227 & 7.47E-04 & 3.9 & 5279 & Beta \\
\hline FTS & MDP & 2000 & 3 & 3312 & $9.22 \mathrm{E}-04$ & 4.9 & 5363 & Beta \\
\hline FTS & MDP & 2001 & 5 & 3068 & $1.36 \mathrm{E}-03$ & 6.9 & 5117 & Beta \\
\hline FTS & MDP & 2002 & 4 & 2986 & $1.18 \mathrm{E}-03$ & 5.9 & 5036 & Beta \\
\hline FTS & MDP & 2003 & 2 & 3149 & $7.59 \mathrm{E}-04$ & 3.9 & 5201 & Beta \\
\hline FTS & MDP & 2004 & 7 & 3127 & $1.73 \mathrm{E}-03$ & 8.9 & 5174 & Beta \\
\hline FTS & MDP & 2005 & 2 & 3058 & $7.72 \mathrm{E}-04$ & 3.9 & 5110 & Beta \\
\hline FTS & MDP & 2006 & 2 & 3001 & $7.81 \mathrm{E}-04$ & 3.9 & 5053 & Beta \\
\hline FTS & MDP & 2007 & 3 & 3005 & $9.78 \mathrm{E}-04$ & 4.9 & 5056 & Beta \\
\hline FTS & MDP & 2008 & 4 & 3090 & $1.16 \mathrm{E}-03$ & 5.9 & 5140 & Beta \\
\hline FTS & MDP & 2009 & 3 & 2942 & $9.90 \mathrm{E}-04$ & 4.9 & 4993 & Beta \\
\hline FTS & MDP & 2010 & 1 & 2985 & $5.85 \mathrm{E}-04$ & 2.9 & 5038 & Beta \\
\hline FTS & MDP & 2011 & 7 & 3032 & $1.76 \mathrm{E}-03$ & 8.9 & 5079 & Beta \\
\hline FTS & MDP & 2012 & 2 & 2701 & $8.30 \mathrm{E}-04$ & 3.9 & 4753 & Beta \\
\hline So & AOV & 1998 & 0 & 569400 & $1.18 \mathrm{E}-07$ & 0.7 & 5780400 & Gamma \\
\hline SO & AOV & 1999 & 0 & 569400 & $1.18 \mathrm{E}-07$ & 0.7 & 5780400 & Gamma \\
\hline SO & AOV & 2000 & 0 & 569400 & $1.18 \mathrm{E}-07$ & 0.7 & 5780400 & Gamma \\
\hline SO & AOV & 2001 & 0 & 613200 & $1.17 \mathrm{E}-07$ & 0.7 & 5824200 & Gamma \\
\hline SO & AOV & 2002 & 0 & 613200 & 1.17E-07 & 0.7 & 5824200 & Gamma \\
\hline SO & AOV & 2003 & 1 & 613200 & $2.88 \mathrm{E}-07$ & 1.7 & 5824200 & Gamma \\
\hline SO & AOV & 2004 & 0 & 613200 & 1.17E-07 & 0.7 & 5824200 & Gamma \\
\hline SO & AOV & 2005 & 0 & 613200 & 1.17E-07 & 0.7 & 5824200 & Gamma \\
\hline SO & AOV & 2006 & 0 & 639480 & $1.16 \mathrm{E}-07$ & 0.7 & 5850480 & Gamma \\
\hline SO & AOV & 2007 & 0 & 613200 & 1.17E-07 & 0.7 & 5824200 & Gamma \\
\hline SO & AOV & 2008 & 0 & 613200 & 1.17E-07 & 0.7 & 5824200 & Gamma \\
\hline SO & AOV & 2009 & 0 & 613200 & 1.17E-07 & 0.7 & 5824200 & Gamma \\
\hline SO & AOV & 2010 & 0 & 613200.0 & 1.17E-07 & 0.7 & 5824200 & Gamma \\
\hline SO & AOV & 2011 & 0 & 613200.0 & $1.17 \mathrm{E}-07$ & 0.7 & 5824200 & Gamma \\
\hline so & AOV & 2012 & 0 & 613200.0 & 1.17E-07 & 0.7 & 5824200 & Gamma \\
\hline SO & MOV & 1998 & 0 & 8383320.0 & $2.26 \mathrm{E}-08$ & 0.6 & 25223320 & Gamma \\
\hline SO & MOV & 1999 & 0 & 8383320.0 & $2.26 \mathrm{E}-08$ & 0.6 & 25223320 & Gamma \\
\hline SO & MOV & 2000 & 0 & 8383320.0 & $2.26 \mathrm{E}-08$ & 0.6 & 25223320 & Gamma \\
\hline SO & MOV & 2001 & 0 & 8383320.0 & $2.26 \mathrm{E}-08$ & 0.6 & 25223320 & Gamma \\
\hline SO & MOV & 2002 & 0 & 8365800.0 & $2.26 \mathrm{E}-08$ & 0.6 & 25205800 & Gamma \\
\hline SO & MOV & 2003 & 0 & 8365800.0 & $2.26 \mathrm{E}-08$ & 0.6 & 25205800 & Gamma \\
\hline SO & MOV & 2004 & 0 & 8365800.0 & $2.26 \mathrm{E}-08$ & 0.6 & 25205800 & Gamma \\
\hline SO & MOV & 2005 & 0 & 8400840.0 & $2.26 \mathrm{E}-08$ & 0.6 & 25240840 & Gamma \\
\hline SO & MOV & 2006 & 0 & 8427120.0 & $2.26 \mathrm{E}-08$ & 0.6 & 25267120 & Gamma \\
\hline SO & MOV & 2007 & 0 & 8418360.0 & $2.26 \mathrm{E}-08$ & 0.6 & 25258360 & Gamma \\
\hline SO & MOV & 2008 & 0 & 8418360.0 & $2.26 \mathrm{E}-08$ & 0.6 & 25258360 & Gamma \\
\hline SO & MOV & 2009 & 0 & 8453400 & $2.25 \mathrm{E}-08$ & 0.6 & 25293400 & Gamma \\
\hline SO & MOV & 2010 & 0 & 8427120 & $2.26 \mathrm{E}-08$ & 0.6 & 25267120 & Gamma \\
\hline SO & MOV & 2011 & 0 & 8549760 & $2.25 \mathrm{E}-08$ & 0.6 & 25389760 & Gamma \\
\hline SO & MOV & 2012 & 0 & 8602320 & $2.24 \mathrm{E}-08$ & 0.6 & 25442320 & Gamma \\
\hline
\end{tabular}


Table 7. Basic event UA trending data.

\begin{tabular}{|c|c|c|c|c|c|c|c|c|}
\hline \multirow{2}{*}{$\begin{array}{l}\text { Failure } \\
\text { Mode }\end{array}$} & \multirow[b]{2}{*}{ Component } & \multirow[b]{2}{*}{ Year } & \multirow{2}{*}{$\begin{array}{l}\text { UA } \\
\text { Hours }\end{array}$} & \multirow{2}{*}{$\begin{array}{l}\text { Critical } \\
\text { Hours }\end{array}$} & \multicolumn{4}{|c|}{ Bayesian Update } \\
\hline & & & & & Mean & Post A & Post B & Distribution \\
\hline UA & MDP & 1998 & 6269.9 & 1029074 & $5.62 \mathrm{E}-03$ & 0.9 & 165.1 & Beta \\
\hline UA & MDP & 1999 & 7476.4 & 1464897 & $4.78 E-03$ & 1.5 & 320.2 & Beta \\
\hline UA & MDP & 2000 & 7568.8 & 1509272 & $4.66 \mathrm{E}-03$ & 2.0 & 426.3 & Beta \\
\hline UA & MDP & 2001 & 8130.5 & 1515574 & $5.36 \mathrm{E}-03$ & 1.1 & 211.2 & Beta \\
\hline UA & MDP & 2002 & 6913.0 & 1584352 & $4.25 \mathrm{E}-03$ & 1.6 & 384.6 & Beta \\
\hline UA & MDP & 2003 & 6568.6 & 1564570 & $3.84 \mathrm{E}-03$ & 1.6 & 414.3 & Beta \\
\hline UA & MDP & 2004 & 6335.2 & 1593290 & $3.79 E-03$ & 1.7 & 439.1 & Beta \\
\hline UA & MDP & 2005 & 5059.1 & 1581917 & $3.21 E-03$ & 1.4 & 422.6 & Beta \\
\hline UA & MDP & 2006 & 5419.2 & 1603890 & $3.33 E-03$ & 1.5 & 447.2 & Beta \\
\hline UA & MDP & 2007 & 4528.0 & 1595246 & $2.88 \mathrm{E}-03$ & 0.8 & 284.9 & Beta \\
\hline UA & MDP & 2008 & 4944.6 & 1589739 & $3.06 \mathrm{E}-03$ & 1.2 & 400.3 & Beta \\
\hline UA & MDP & 2009 & 5302.7 & 1598473 & 3.37E-03 & 1.4 & 409.5 & Beta \\
\hline UA & MDP & 2010 & 4956.7 & 1561767 & $3.20 E-03$ & 1.4 & 441.5 & Beta \\
\hline UA & MDP & 2011 & 5359.8 & 1551044 & $3.38 E-03$ & 1.3 & 386.0 & Beta \\
\hline UA & MDP & 2012 & 5375.3 & 1528794 & $3.36 \mathrm{E}-03$ & 1.2 & 349.6 & Beta \\
\hline
\end{tabular}

Table 8. Failure mode acronyms.

\begin{tabular}{ll}
\hline \multicolumn{1}{c}{ Failure Mode } & \multicolumn{1}{c}{ Failure Mode Description } \\
\hline FTOC & Fail to Open/Close \\
FTOP & Fail to Operate \\
FTR $>1 \mathrm{H}$ & Fail to Run greater than one hour \\
FTR $<1 \mathrm{H}$ & Fail to Run less than one hour (after start) \\
FTS & Fail to Start \\
SO & Spurious Operation \\
UA & Unavailability (Maintenance or State of another component) \\
\hline
\end{tabular}


System Study

High-Pressure Safety Injection 


\section{SYSTEM DESCRIPTION}

The HPSI system is part of the Emergency Core Cooling System (ECCS) that performs emergency coolant injection and recirculation functions to maintain reactor core coolant inventory and adequate decay heat removal following a loss-of-coolant accident (LOCA). The coolant injection function is performed during a relatively short-term period after LOCA initiation, followed by realignment to a recirculation mode of operation to maintain long-term, post-LOCA core cooling. In addition to the above, reactors which are equipped with pressurizer (PZR) power operated relief valves (PORVs) could use the PORVs and HPSI to remove decay heat from the reactor in the event of the loss of the Main Feedwater (MFW) and Auxiliary Feedwater (AFW ) systems.

The HPSI system actuates automatically on low PZR pressure, high containment pressure, or when steam line pressure or flow anomalies are detected. Therefore, in addition to a LOCA, other events will lead to HPSI actuation. Some examples of such events are Steam Generator Tube Ruptures (SGTRs), RCS overcooling events resulting from steam line breaks (e.g., Stuck open main steam safety valves), or RCS depressurization events (e.g., stuck open PZR spray valves). The HPSI SPAR models were analyzed using the SLOCA initiator flag.

The HPSI systems analyzed have been grouped into three different design classes as shown in Table 1. The criteria used to determine this grouping was the number of charging pumps, intermediatehead, and high-head safety injection trains available for automatic actuation used in the SPAR models. Each system typically consists of at least two independent divisions. The divisions consist of a number of different combinations of motor-driven pump trains. Because of the diversity in system design, operation, and response to plant transients, a detailed discussion of the each plant-specific system is not practical. A general description is provided for the two major designs utilizing high head or intermediate head functional schemes. Differences among the other types of system design classes are also discussed. Table 9 summarizes the plants and their assigned classes.

SPAR modeling of the HPSI incorporates the plant-to-plant design and operational differences indicated in Table 9. All ac emergency power sources that either are automatically started and aligned to essential buses given a LOOP or can be manually started and aligned within approximately 30 minutes are included in the HPSI SPAR fault trees. Included in the HPSI SPAR fault trees are dependencies such as room cooling, service water cooling, and DC power.

The HPSI system is typically not in service during normal plant operations except for the charging pumps. It is considered part of the ECCS and is used to restore primary coolant volume during LOCAs, depressurization events, and overcooling events. However, the HPSI systems have wide variation from vendor to vendor and from plant to plant. In some plants, B\&W in particular and some Westinghouse designs, the normal make-up pumps are also the HPSI pumps, and therefore a portion of the HPSI system is in service during normal modes of plant operation. The Combustion Engineering and other Westinghouse designs commonly use a charging system for normal make-up that is separate from the safety injection pumps, which are used only during emergency or abnormal situations. However, even in these designs the make-up and safety injection systems are inter-related because they share common valves, water sources, piping runs, and other equipment. Consequently, the safety injection systems can be either intermediate-head capacity (approximately $1400 \mathrm{psi}$ ), or high-head capacity (approximately 2200 psi) depending on whether they are used for normal charging (high-head) or not (intermediatehead). These differences in system pressure and postulated break size determine how it is used during emergencies.

The HPSI system is typically started automatically by the engineered safety features actuation system (ESFAS) or equivalent, depending on plant design and terminology. Generally, the ESFAS automatic start signal set points include a low reactor coolant system pressure or a high reactor building (i.e., containment) pressure signal. There can be additional start signals, but these two are typical. 
Table 9. HPSI design class summary.

\begin{tabular}{|c|c|c|c|c|}
\hline Class & Plant & Total & $\begin{array}{c}\text { CVC } \\
\text { Pumps }\end{array}$ & $\begin{array}{c}\text { HPSI } \\
\text { Pumps }\end{array}$ \\
\hline Class 2 & Harris & 3 & & $3^{a}$ \\
\hline Class 2 & Kewaunee & 2 & & 2 \\
\hline Class 2 & Palisades & 2 & & 2 \\
\hline Class 2 & Palo Verde 1 & 2 & & 2 \\
\hline Class 2 & Palo Verde 2 & 2 & & 2 \\
\hline Class 2 & Palo Verde 3 & 2 & & 2 \\
\hline Class 2 & Point Beach 1 & 2 & & 2 \\
\hline Class 2 & Point Beach 2 & 2 & & 2 \\
\hline Class 2 & Prairie Island 1 & 2 & & 2 \\
\hline Class 2 & Prairie Island 2 & 2 & & 2 \\
\hline Class 2 & St. Lucie 1 & 2 & & 2 \\
\hline Class 2 & St. Lucie 2 & 2 & & 2 \\
\hline Class 2 & Summer & 2 & & 2 \\
\hline Class 3 & Arkansas 1 & 3 & & 3 \\
\hline Class 3 & Arkansas 2 & 3 & & 3 \\
\hline Class 3 & Beaver Valley 1 & 3 & & 3 \\
\hline Class 3 & Beaver Valley 2 & 3 & & 3 \\
\hline Class 3 & Calvert Cliffs 1 & 3 & & 3 \\
\hline Class 3 & Calvert Cliffs 2 & 3 & & 3 \\
\hline Class 3 & Crystal River 3 & 3 & & 3 \\
\hline Class 3 & Farley 1 & 3 & 3 & \\
\hline Class 3 & Farley 2 & 3 & 3 & \\
\hline Class 3 & Fort Calhoun & 3 & & 3 \\
\hline Class 3 & Ginna & 3 & & 3 \\
\hline Class 3 & Indian Point 2 & 3 & & 3 \\
\hline Class 3 & Indian Point 3 & 3 & & 3 \\
\hline Class 3 & Millstone 2 & 3 & & 3 \\
\hline Class 3 & North Anna 1 & 3 & & 3 \\
\hline Class 3 & North Anna 2 & 3 & & 3 \\
\hline Class 3 & Oconee 1 & 3 & & 3 \\
\hline Class 3 & Oconee 2 & 3 & & 3 \\
\hline Class 3 & Oconee 3 & 3 & & 3 \\
\hline Class 3 & Robinson 2 & 3 & & 3 \\
\hline Class 3 & San Onofre 2 & 3 & & 3 \\
\hline Class 3 & San Onofre 3 & 3 & & 3 \\
\hline
\end{tabular}

\begin{tabular}{|c|c|c|c|c|}
\hline Class & Plant & Total & $\begin{array}{l}\text { CVC } \\
\text { Pumps }\end{array}$ & $\begin{array}{c}\text { HPSI } \\
\text { Pumps }\end{array}$ \\
\hline Class 3 & South Texas 1 & 3 & & 3 \\
\hline Class 3 & South Texas 2 & 3 & & 3 \\
\hline Class 3 & Surry 1 & 3 & & 3 \\
\hline Class 3 & Surry 2 & 3 & & 3 \\
\hline Class 3 & Three Mile Island 1 & 3 & & 3 \\
\hline Class 3 & Waterford 3 & 3 & & 3 \\
\hline Class 4 & Braidwood 1 & 4 & 2 & 2 \\
\hline Class 4 & Braidwood 2 & 4 & 2 & 2 \\
\hline Class 4 & Byron 1 & 4 & 2 & 2 \\
\hline Class 4 & Byron 2 & 4 & 2 & 2 \\
\hline Class 4 & Callaway & 4 & 2 & 2 \\
\hline Class 4 & Catawba 1 & 4 & 2 & 2 \\
\hline Class 4 & Catawba 2 & 4 & 2 & 2 \\
\hline Class 4 & Comanche Peak 1 & 4 & 2 & 2 \\
\hline Class 4 & Comanche Peak 2 & 4 & 2 & 2 \\
\hline Class 4 & Cook 1 & 4 & 2 & 2 \\
\hline Class 4 & Cook 2 & 4 & 2 & 2 \\
\hline Class 4 & Davis-Besse & 4 & 2 & 2 \\
\hline Class 4 & Diablo Canyon 1 & 4 & 2 & 2 \\
\hline Class 4 & Diablo Canyon 2 & 4 & 2 & 2 \\
\hline Class 4 & McGuire 1 & 4 & 2 & 2 \\
\hline Class 4 & McGuire 2 & 4 & 2 & 2 \\
\hline Class 4 & Millstone 3 & 4 & 2 & 2 \\
\hline Class 4 & Salem 1 & 4 & 2 & 2 \\
\hline Class 4 & Salem 2 & 4 & 2 & 2 \\
\hline Class 4 & Seabrook & 4 & 2 & 2 \\
\hline Class 4 & Sequoyah 1 & 4 & 2 & 2 \\
\hline Class 4 & Sequoyah 2 & 4 & 2 & 2 \\
\hline Class 4 & Turkey Point 3 & 4 & & 4 \\
\hline Class 4 & Turkey Point 4 & 4 & & 4 \\
\hline Class 4 & Vogtle 1 & 4 & 2 & 2 \\
\hline Class 4 & Vogtle 2 & 4 & 2 & 2 \\
\hline Class 4 & Watts Bar 1 & 4 & 2 & 2 \\
\hline Class 4 & Wolf Creek & 4 & 2 & 2 \\
\hline
\end{tabular}


As mentioned before, in some PWRs, the normally running charging pumps are used to perform the HPSI function. In these plants, during normal operations, the charging-pump/make-up pump takes suction from the volume control tank (VCT)/make-up tank (MUT). The level in this tank is maintained from letdown received from the purification loop of the reactor coolant system (RCS), reactor coolant pump (RCP) seal return, charging/make-up pump recirculation, and other minor sources. Borated water is added to the VCT/MUT occasionally depending on losses in the system, such as RCS leakage or operational requirements to borate or de-borate. During emergency operation, the suction of the charging/make-up pumps is changed. Several valves reposition automatically upon receipt of a safety injection signal. This allows a large reserve tank to supply borated water to the suction of the charging/safety injection pumps. This large tank is commonly called the refueling water storage tank (RWST) or borated water storage tank (BWST). The water in this tank has a high boron concentration, generally $2400 \mathrm{ppm}$ boron. The tank volume varies from about 245,000 to as high as 450,000 gallons but is often in the 338,000 to 425,000 gallon range. Once the valves have repositioned, the head from the RWST/BWST seats the VCT/MUT outlet check valve, and thereby the highly borated water is supplied to the safety injection (SI) pumps.

During emergency situations, when the water in the RWST/BWST is depleted, water is available to the HPSI pumps from the reactor building or containment building sump. This water may be directly available to the SI pumps via piping and valves or it may require a low-pressure stage pump to provide sufficient net positive suction head (NPSH) to the SI and charging/make-up pumps. This source of water becomes extremely important during emergencies that require a prolonged time for injection before being terminated and possibly exhausting the RWST/BWST water capacity. In this case, the HPSI system is used in the "recirculation mode."

The above discussion mainly applies to designs where the charging/make-up pumps used in normal operation are also the HPSI pumps during emergencies. These pumps require the low-pressure pumps to provide NPSH from the reactor building or containment building sump, for example Oconee 1, 2, and 3 utilize this design. The following applies to those designs that incorporate separate SI pumps and charging/make-up pumps. For these designs, the charging/make-up pumps operate the same as mentioned above. That is, during normal operation the charging pumps take suction from the VCT/MUT. However, upon receipt of a safety injection signal, the pumps take suction from the RWST and the valves between the VCT/MUT and the charging pump suction close (typically, there are two valves). However, the dedicated SI pumps can only take water from the RWST/BWST and not the VCT/MUT like the charging/make-up pumps. These SI pumps are intermediate head. The intermediate-head SI pumps will require the charging/make-up pumps to be in operation until the RCS press decreases to the pressure where the intermediate-head pumps can inject water. At this point, the charging/make-up pumps can be turned off or left on to help inject a greater volume of water. Braidwood 1 and 2 are an example of this design. The final plant design contains only intermediate-head SI pumps that are used for HPSI . These pumps take suction from the RWST/BWST for injection and are aligned to take suction directly from the reactor building or containment build sump during "recirculation mode." Waterford is an example of this design.

In the plants equipped with charging/make-up pumps and dedicated SI pumps, typically, during normal operation, the charging/make-up pumps supply make-up or cooling water to plant equipment. One is the RCP seal supply. This normally requires 8 to $10 \mathrm{gpm}$ per reactor coolant pump. Another function is pressurizer level control. This system senses pressurizer level and opens or closes the pressurizer level control valve allowing more or less make-up to maintain the selected pressurizer level set point. Most of the flow from the charging/make-up pumps is returned to the VCT/MUT via recirculation piping and valves during normal system operation. Once an ECCS signal is received or the operator manually repositions valves to their emergency position, the discharge of the charging/make-up pumps is redirected. There are generally three or four injection nozzles to the RCS for HPSI . These nozzles, located in the cold legs of the RCS have instrumented piping connected to them from the 
charging/make-up pumps and SI pumps depending on the design. Some of the devices and instrumentation on the discharge piping include, but is not limited to injection/isolation valves, flowbalancing orifices, flow crossover piping, and nozzle and total flow indicators. The flow from the SI and the charging/make-up pumps to the RCP seals is reduced. The charging/make-up pump recirculation back to the VCT/MUT is also automatically terminated in order to maximize SI flow into the RCS. 


\section{REFERENCES}

1. Nuclear Regulatory Commission, Component Reliability Data Sheets Update 2010, January 2012, http://nrcoe.inl.gov/resultsdb/publicdocs/AvgPerf/ComponentReliabilityDataSheets2010.pdf

2. S.A. Eide et al., Industry-Average Performance for Components and Initiating Events at U.S. Commercial Nuclear Power Plants, Nuclear Regulatory Commission, NUREG/CR-6928, February 2007. 
System Study

High-Pressure Safety Injection
2012 Update October 2013 